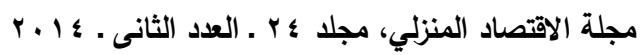

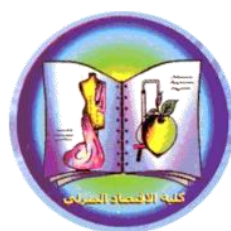

$$
\begin{aligned}
& \text { مجلة الاقتصاد المنزلي }
\end{aligned}
$$

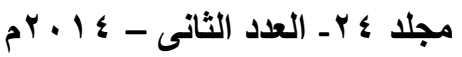

\title{
Journal of Home
}

Economics

ISSN 1110-2578 http://homeEcon.menofia.edu.eg

\section{فاعلية برنامج فى التنمية المستدامة والتربية الأسرية قائم على استراتيجية

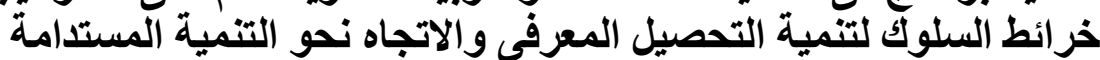 لاطبالباث المعلمات}

\section{زيزى حسن عمر}

مدرس مناهج وطرق تدريس - كلية التربية النو عية - جامعة الاسكندرية

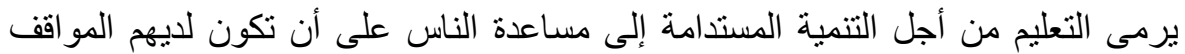

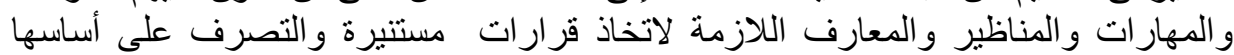

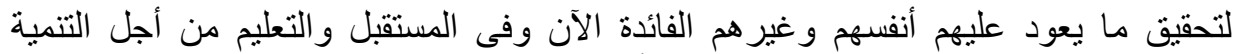

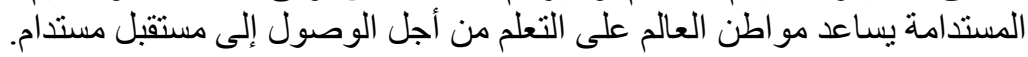

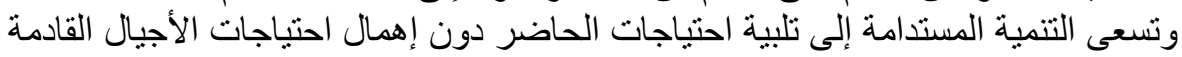

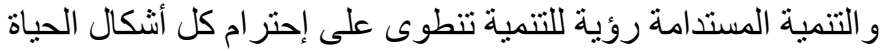

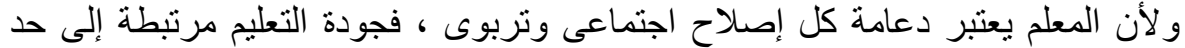

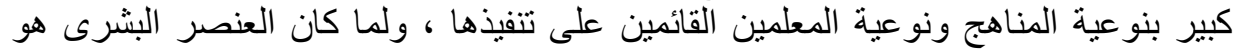

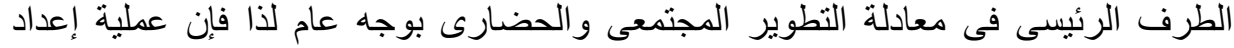

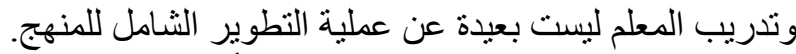

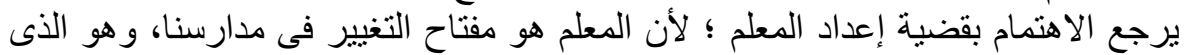

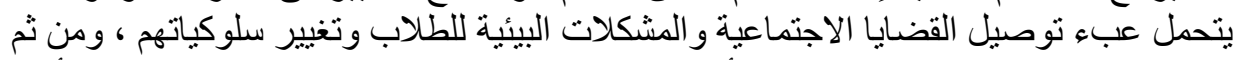

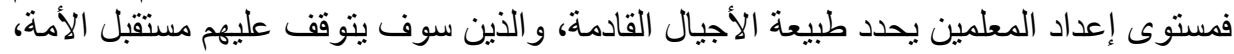

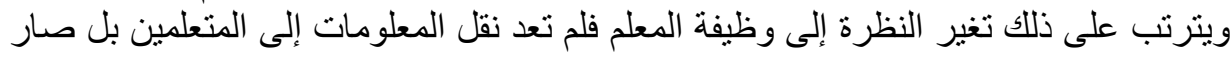

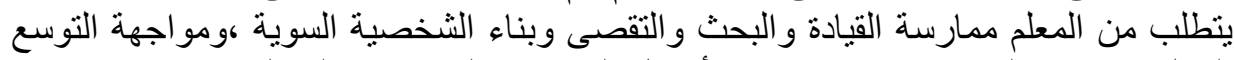

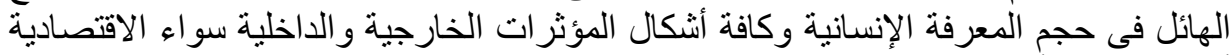
أو الاجتماعية أو السياسية. وتعد قضية التنمية واحدة من أكثر القضايا أهمية وحساسية فى القرن الواحد و العشرين

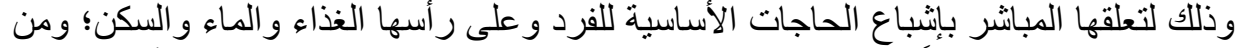

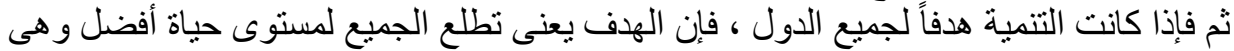

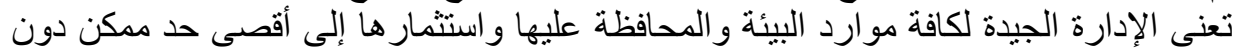

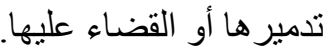

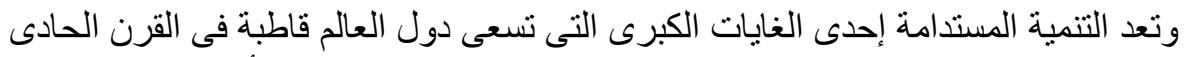

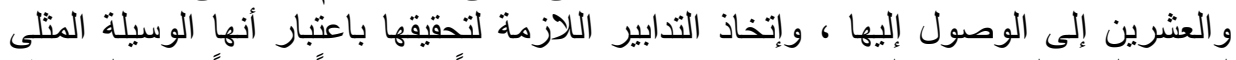

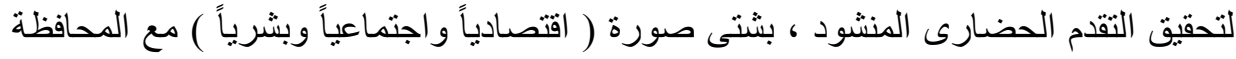




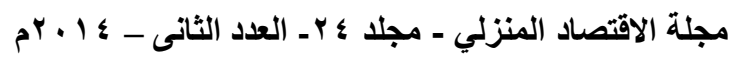

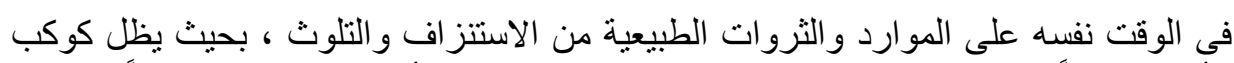

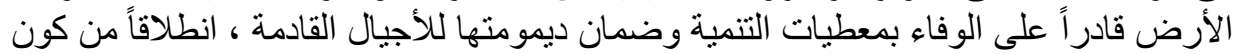

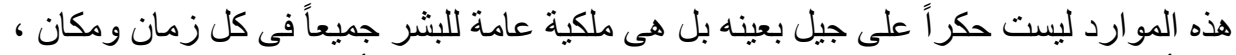

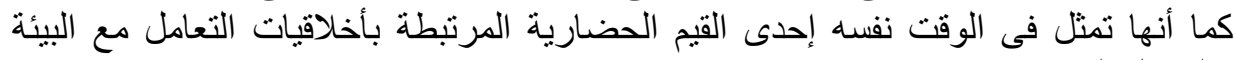

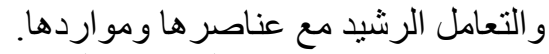

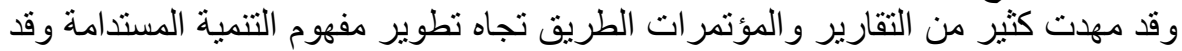

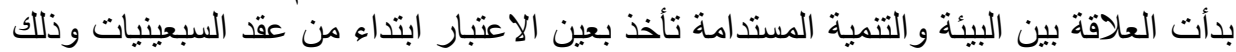

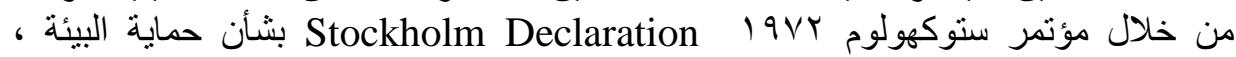

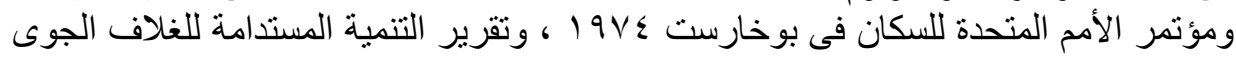

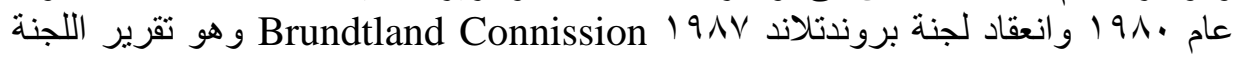

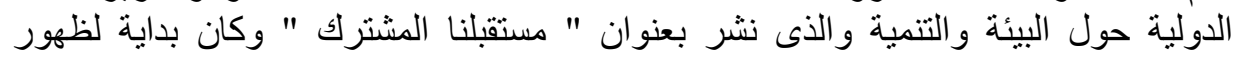

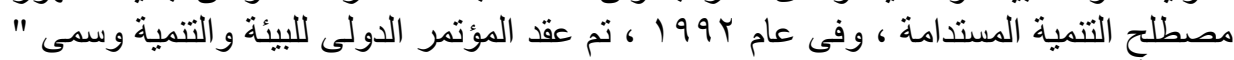

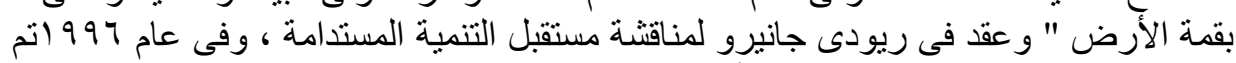
The United Nations Commission إنشاء إدارة التنمية المستدامة التابع للأمم المتحدية التحدية (Rio +S ) و وفى عام Sustainable Development (CSD)

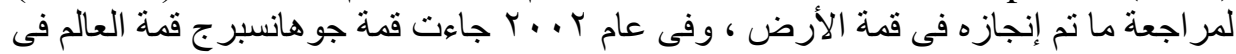

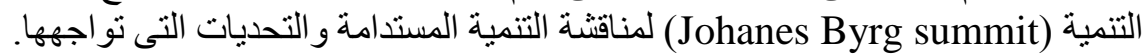

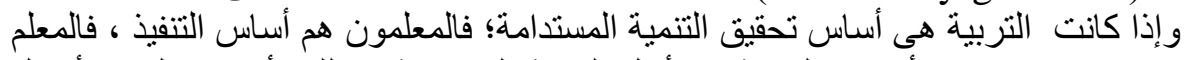

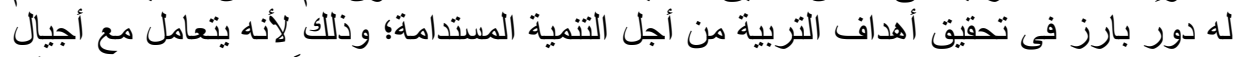

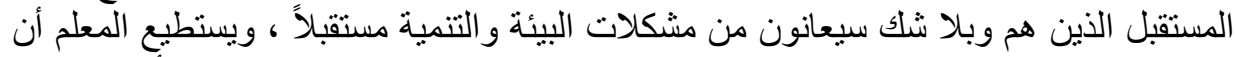

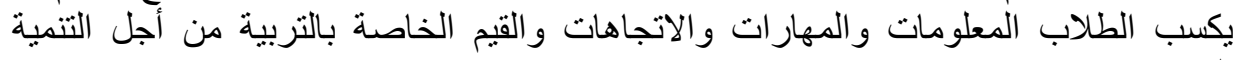

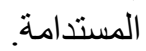

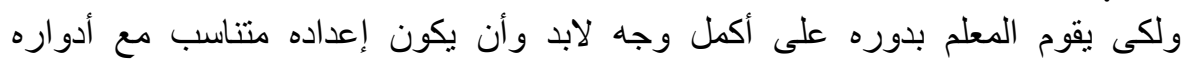

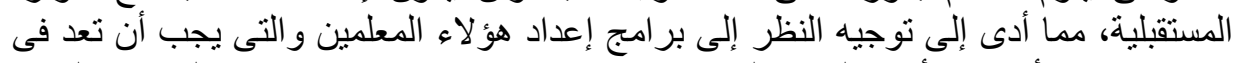

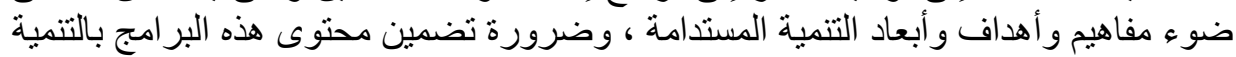
المستدامة وتحديد معوقات تدريسها.

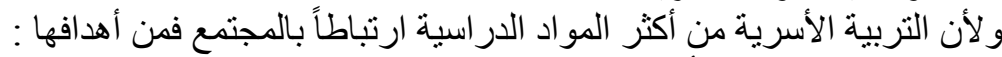

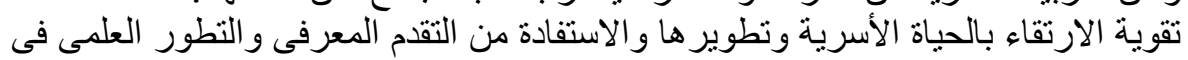

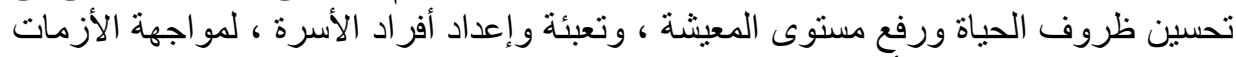

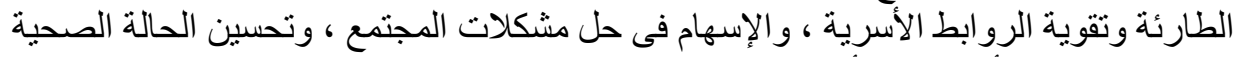

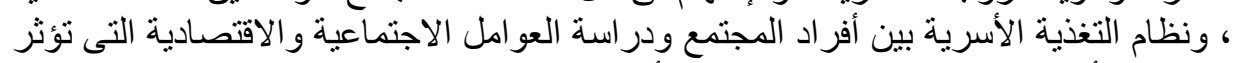

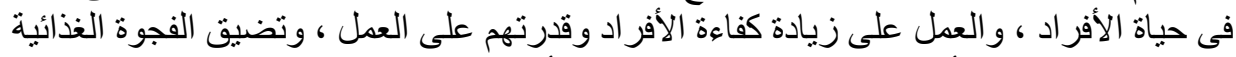

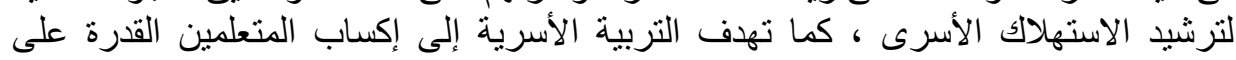

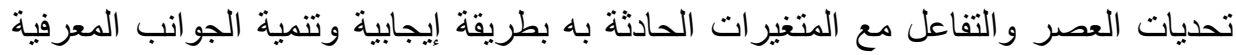

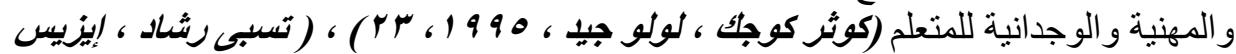

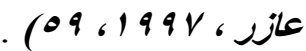

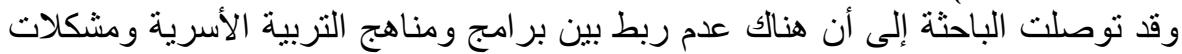

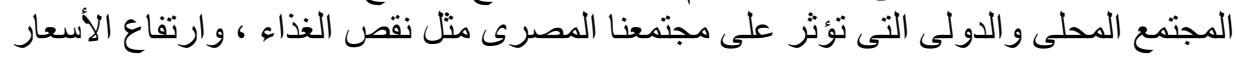




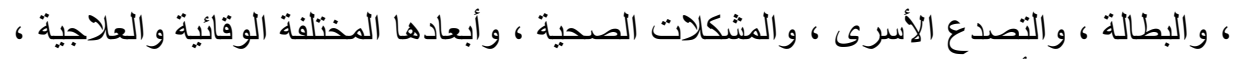

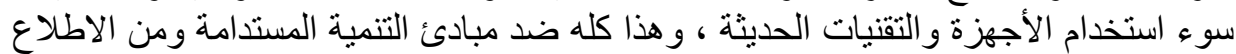

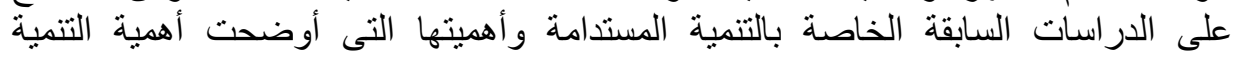

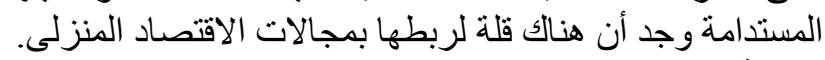

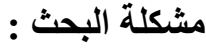

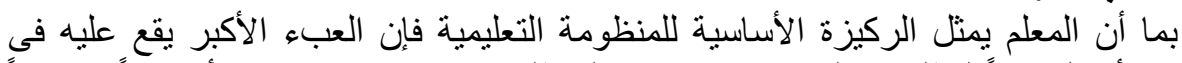

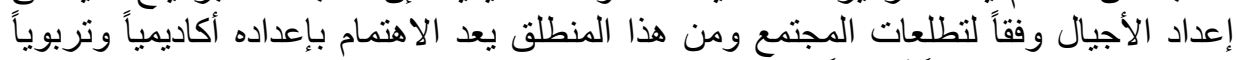

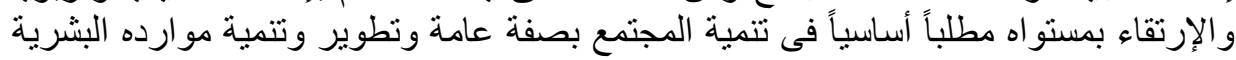

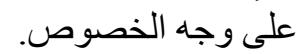

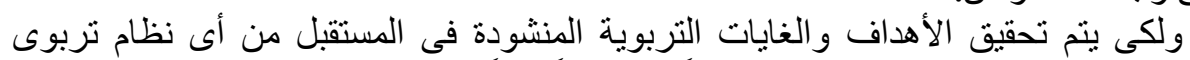

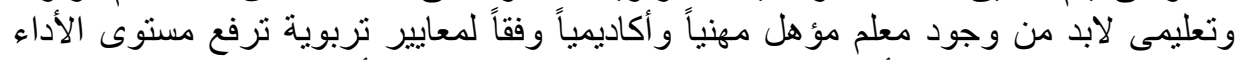

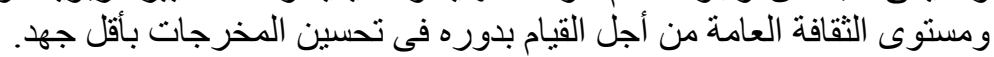

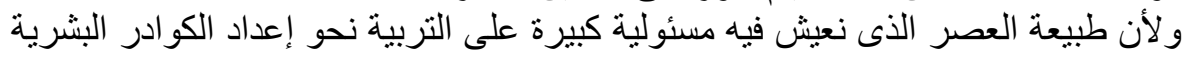

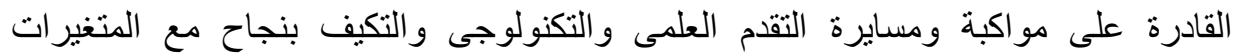

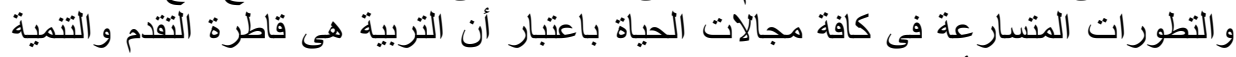

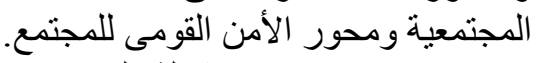

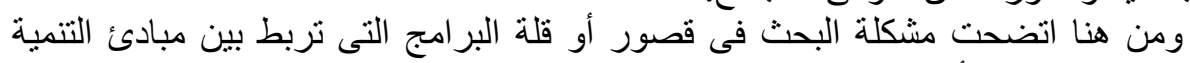

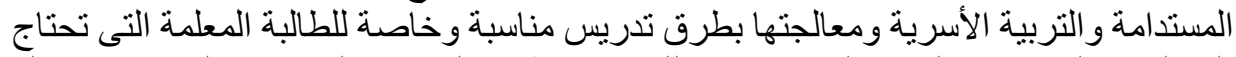

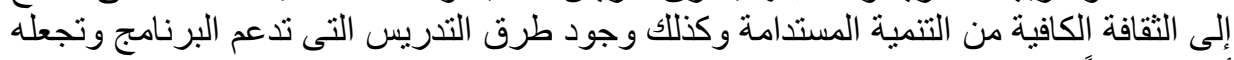

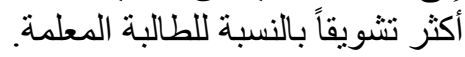

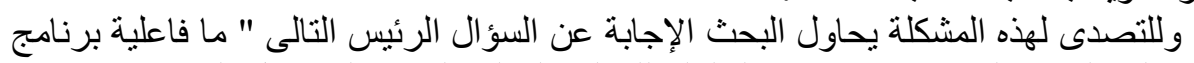

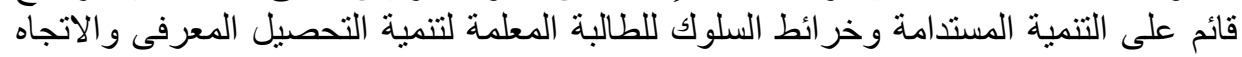

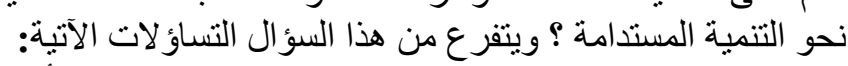

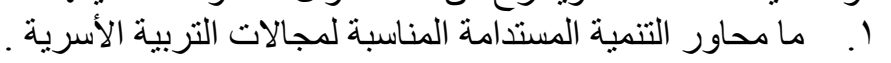

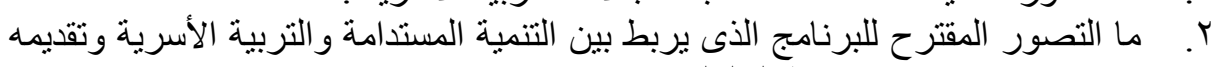

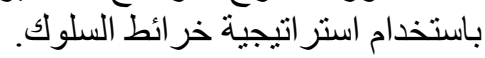

r. ما مدى فاعلية البرنامج فى زئية زيادة التحصيل المعرفى وتنمية الاتجاه نحو التنمية

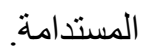

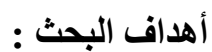

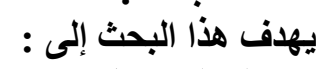

اـ إعداد برنامج منصل بالثلثربية الأسرية ومبادئ التتمية المستدامة باستخدام إستراتيجية

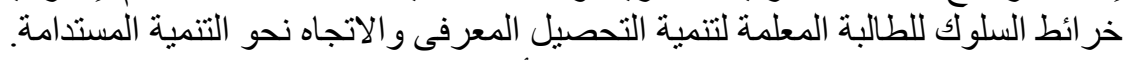

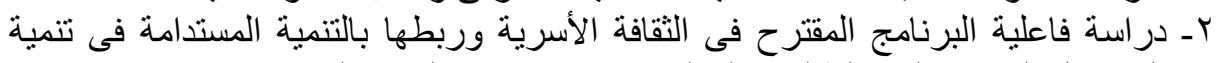

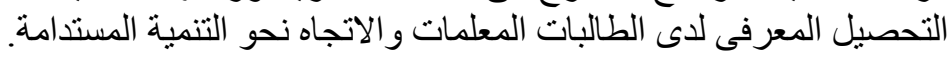
أهمية البحث : البحئ

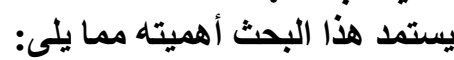
ا ـ قد يفيد هذا البحث في إكساب الطالبات المعلمات لمفاهيم التنمية المستدامة وربطها بالتربية

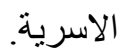


r- يعد هذا البحث استجابة لما تتادى به الاتجاهات الحالية لأهمية و إبراز التتمية المستدامة وربطها بكل تفاصيل الحياة الأسرية وانية المجنمعية.

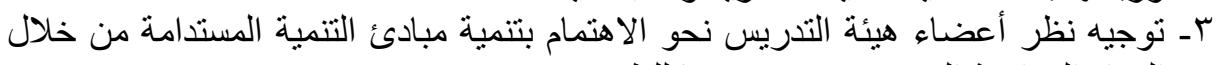

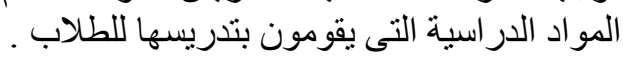

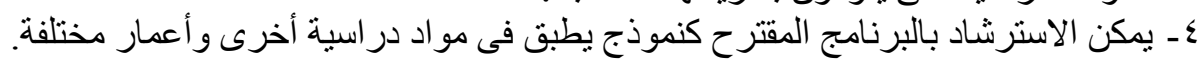

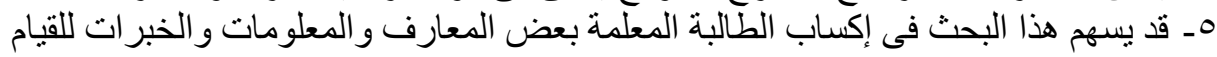
بمهامهم الحياتية بطريقة مثلى.

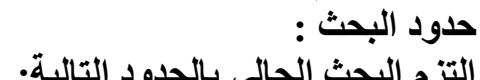

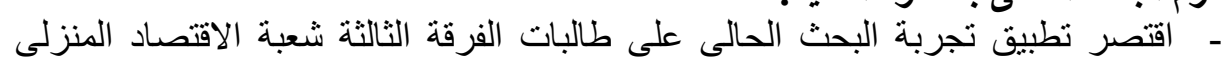
بكلية التربية النو عية بالإسكندرية.

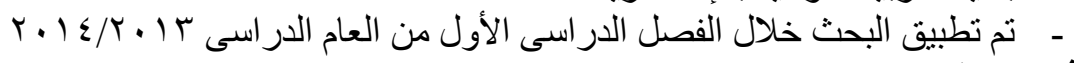

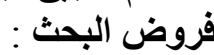
1 - يوجد فرق دال إحصائياً بين منوسطي درجات الطالبات في التطبيق القبلى و البعدى لكلا

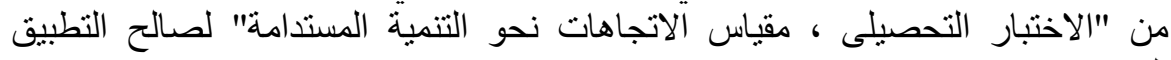

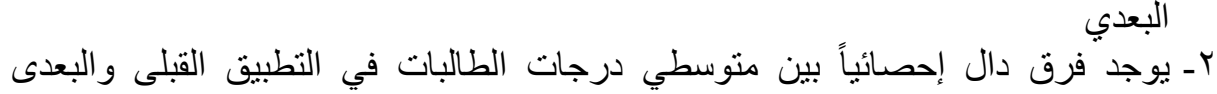

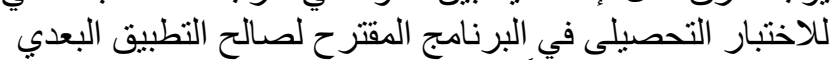

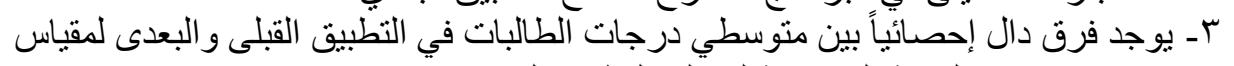

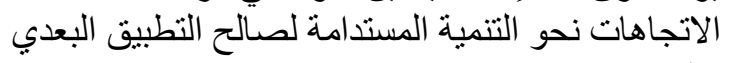

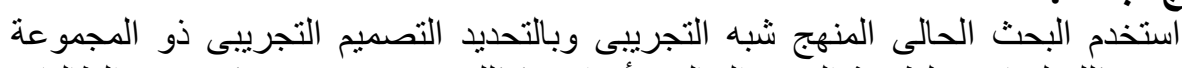
منهج البحث : ماهن

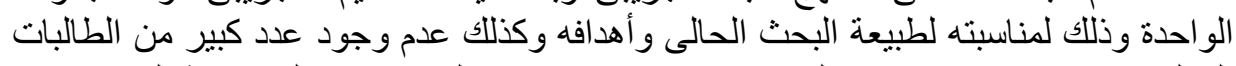

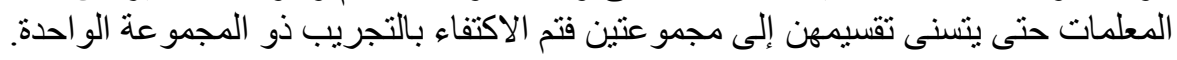

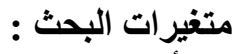

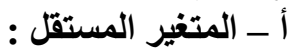

برنامج مقتر ح فى التنمية المستدامة و التربية الأسرية قائم على استر اتيجية خر ائط السلوك.

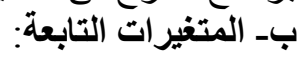

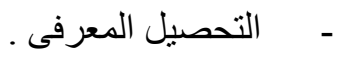

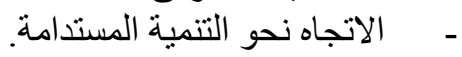
أدوات البحث : الخباه

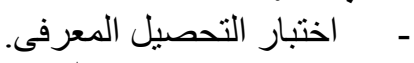
- مقاس - مقاس الاتجاه نحو التنمية المستدامة. 
هى الربط بين مبادئ التنمية المستدامة و التربية الأسرية بكل مجالاتها المتتو عة حتى يمكننا تحسين نوعية الحياة لكل أفر اد الأسرة والئن المجتمع.

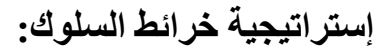

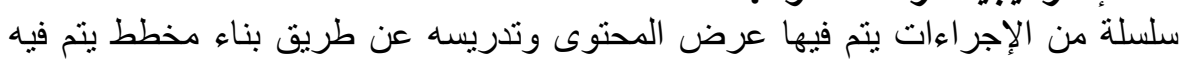

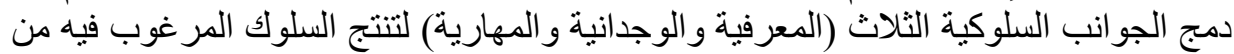

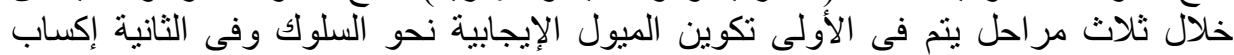

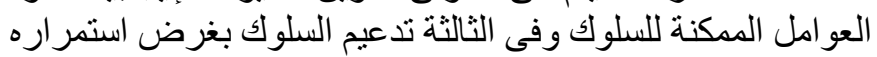

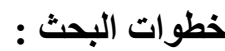

للإجابة عن أسئلة البحث البعت الباحثة الخطوات التالية:

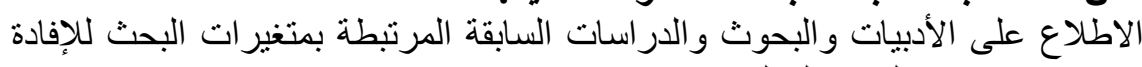

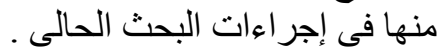

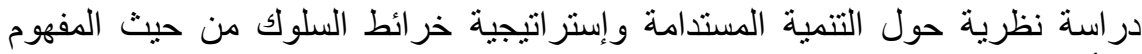

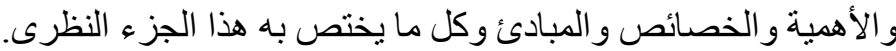

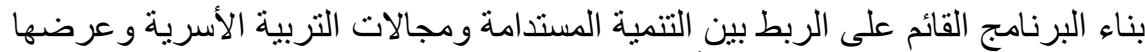

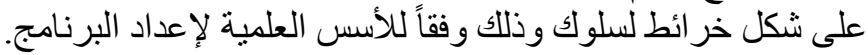

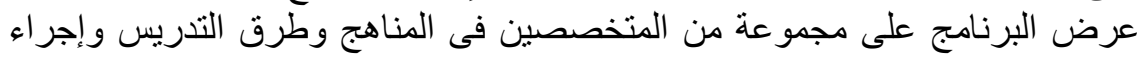

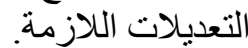
عمل استبانه خاص بمبادئ ومحادئ ولاور التنمية المستدامة لاختبار الأنسب لطبيعة مجالات

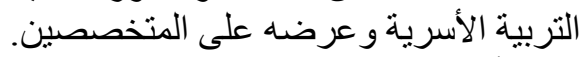

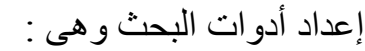
استبيان لمحاور ومبادئ التنمية المستدامة.

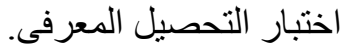
مقياس الاتجاه نحو التنمية المستدامة.

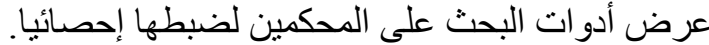
إختبار مجمو عة البحث من الطالبات المعلمات للفر الفرة الثنالثة شعبة الاقتصاد المنزلى بكلية التربية النو عية بالإسكندرية. تطبيق أداتى البحث تطبيقاً قبلياً على مجمو عة البحث.

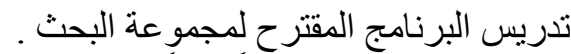

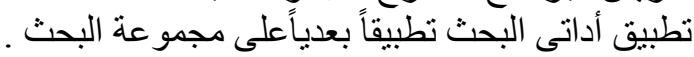

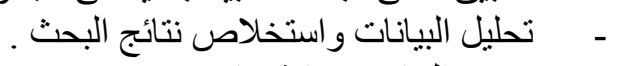

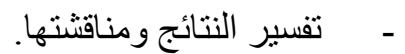
- - - تقديم التوصيات و المقترحات المناسبة فى ضوء النتائج التى يتوصل إليها البحث.

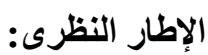
ينكون من محورين ( التنمية المستدامة ـ إستر اتيجية خر ائط السلوك). 


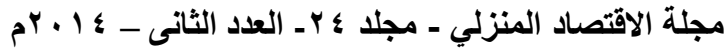

المحول الأول : التنمية المستدامة

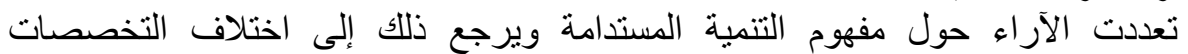

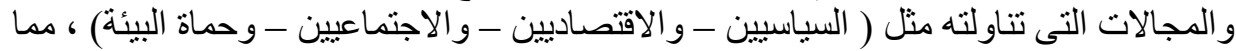
أدى إلى وجود العديد من التعريفات للتنمية المستدامة. فمن الناحية اللغوية يشير مصطلح الاستدامة Sustainable إلى الدعم الطويل الأجل أو الو الدئ

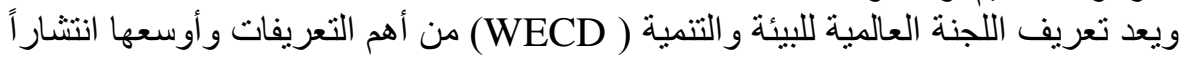

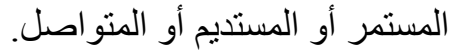

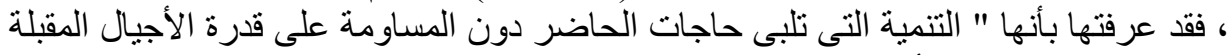

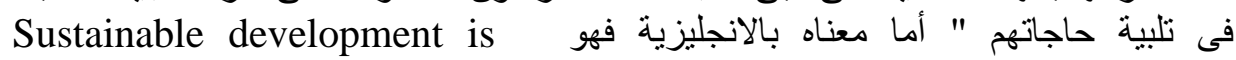
development that meets the needs of the present without compromising the ability of future generations to meet their own needs

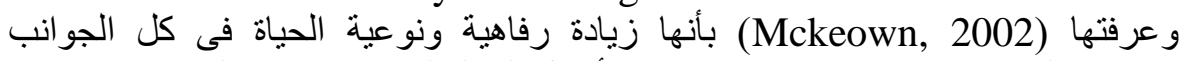

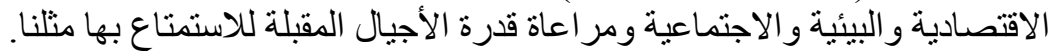
معوقات وتحديات التنمية المستدامة:

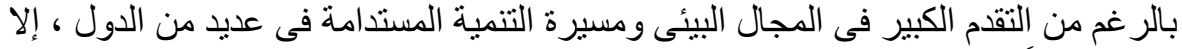

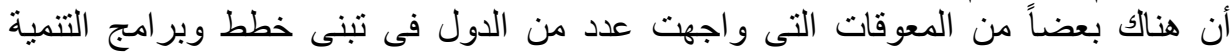

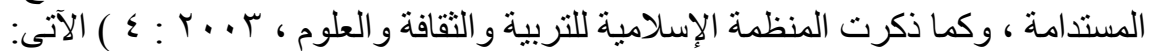
1- الفقر : وهو أساس لكثير من المعضلات الصحية والاجتماعية والأزمات النفسية الأنية

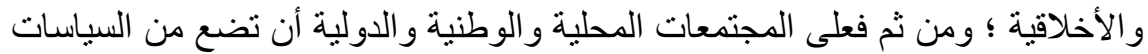

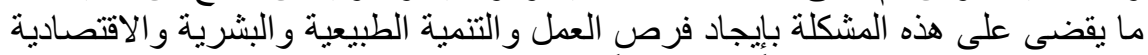

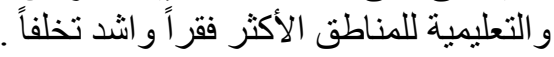

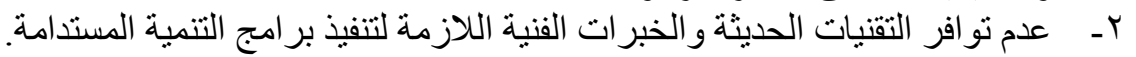

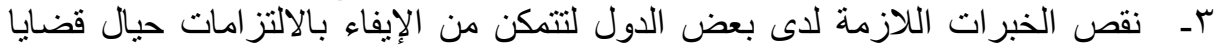

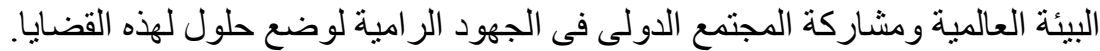

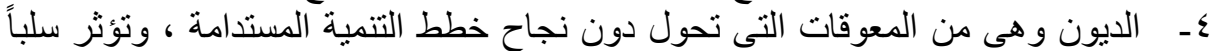

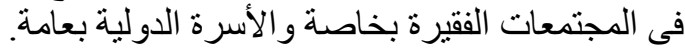

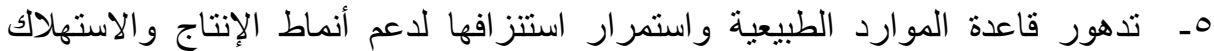
الحالية ، مما يزيد من نضوب قاعدة الماردة ولموارد الطبيعة و إعاقة تحقيق التنمية المستدامة فى الإنى

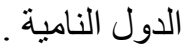
أما التحديات فهى كثيرة سنذكر منها : لأنهات

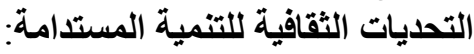

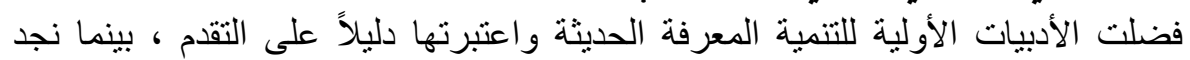

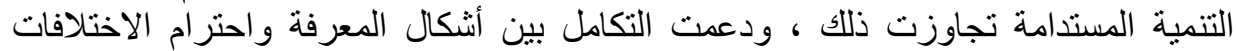

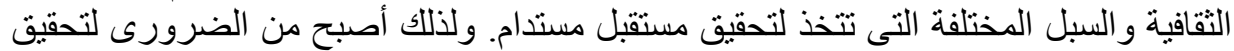

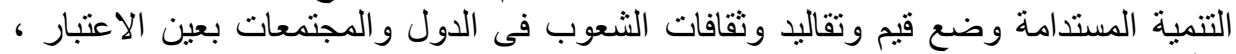

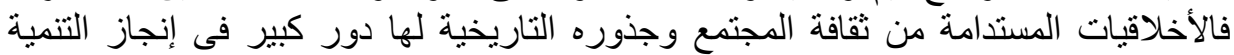

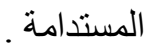




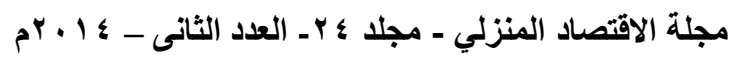

•

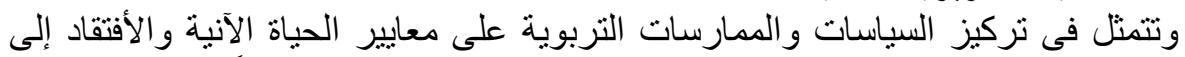

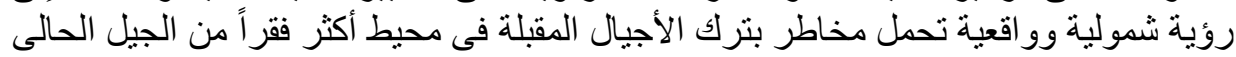

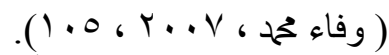

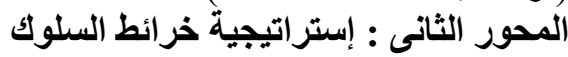

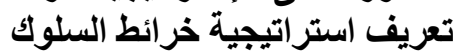

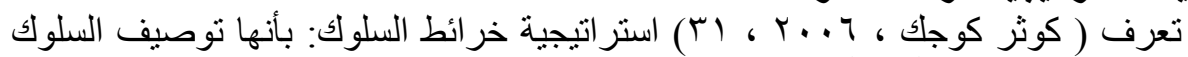

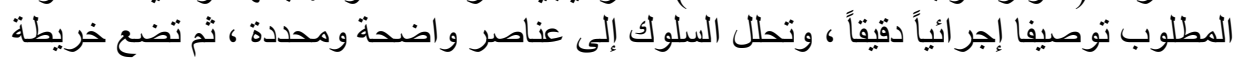

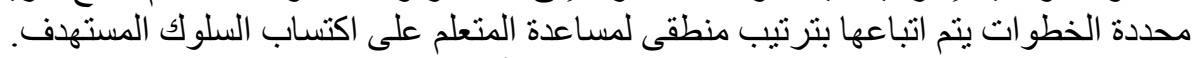

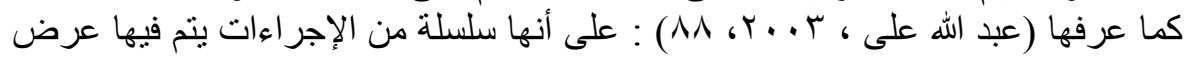

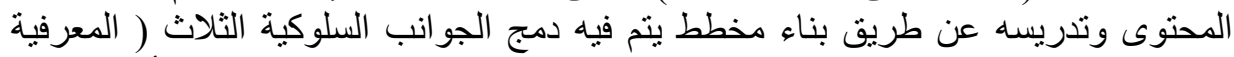

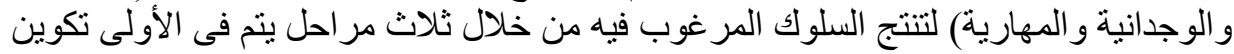
الميول الإيجابية نحو السلوك وفى الثانية إكساب العوانية الثل الممكنة للسلوك وفى الثى الثالثة تدعيم

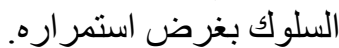

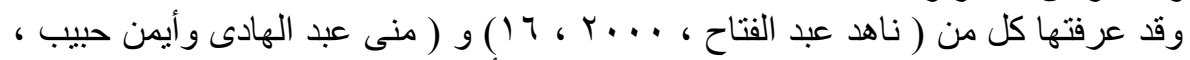

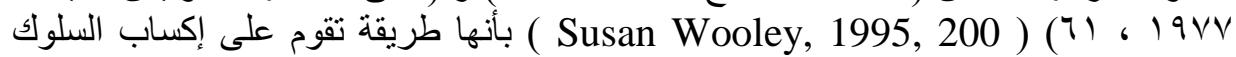

$$
\begin{aligned}
& \text { المستهدف من خلال ثلاث مر احل منتابعة هى: }
\end{aligned}
$$

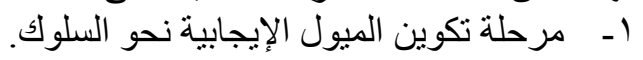

$$
\begin{aligned}
& \text { r - مرحلة إكساب العو امل الممكنة من السلوك. }
\end{aligned}
$$

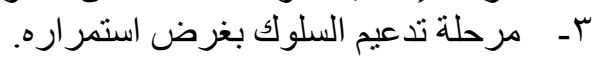

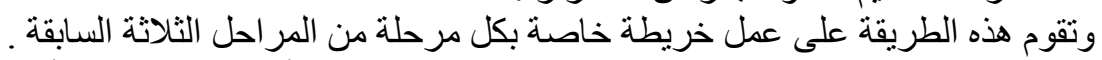

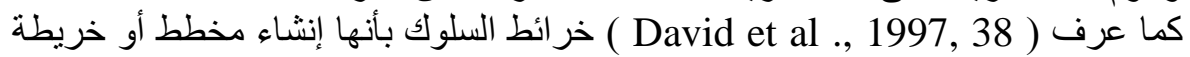

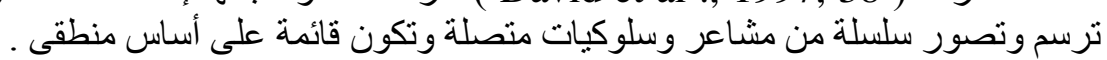

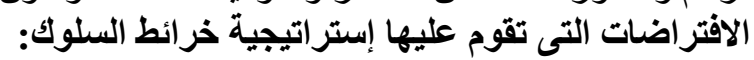

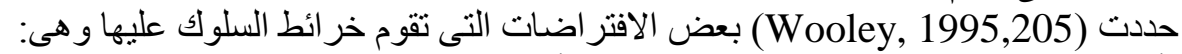

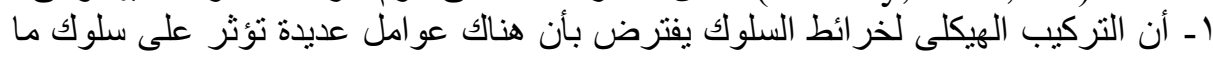

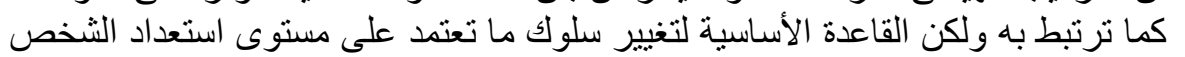

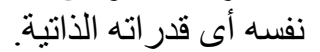

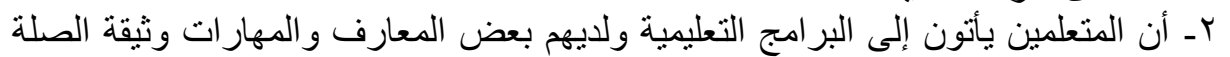

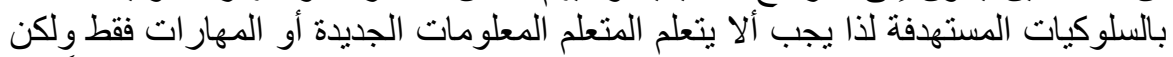

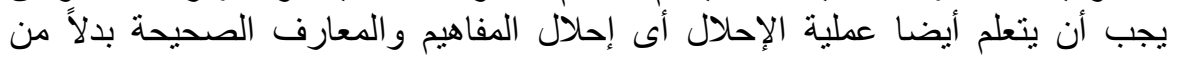
الخاطئة التى كانت لديهر.

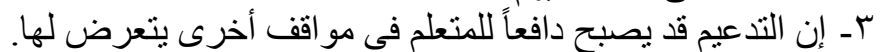

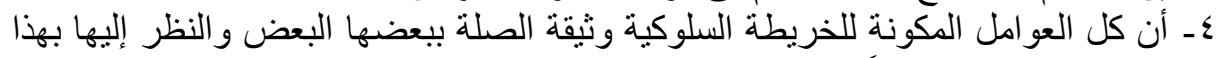
الثكل يعتبر مطلبا هاماً لتغير السلوك. النك. 


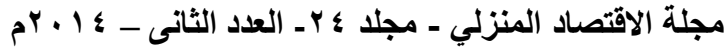

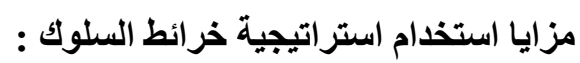

من خلال التحليل الاقيق لخر ائط السلوك توك توصلت الباحثة إلى أن خرائط السلوك لها أهمية

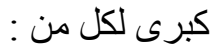

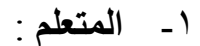

تزيد من دافعيته ورغبته فى التعلم مما يزيد من انتباهه للموقف التعليمى والإقبال عليه

$$
\text { بنشاط حتى يتحقق التعلم المنشود. }
$$

تزود المتعلم بالمعرفة الوظيفية أى بالمعلومات التى يحتاجها لتجنب السلوكيات الخاطئة و واكنساب السلوكيات الصحيحة.

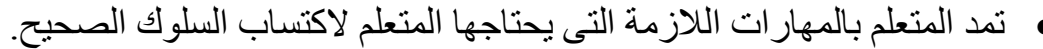

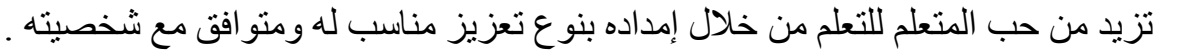

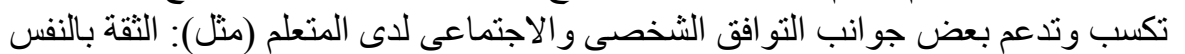

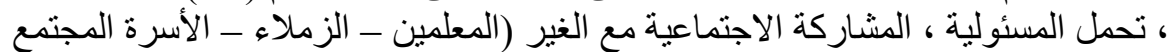

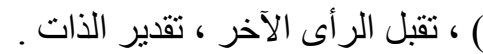

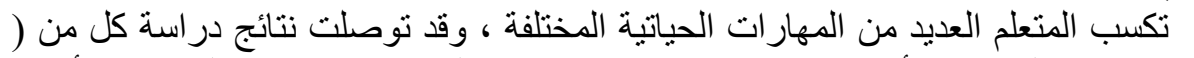

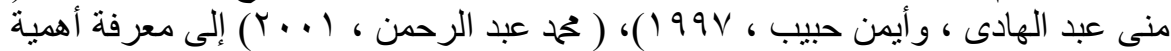
استراتيجية خرائط السلوك فى تنمية قدرة المتعلم على التصرف في المى المواقف الحياتية

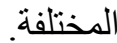

• تجعل دور المتعلم نشطاً و إيجابياً في العملية التعليمية من خلال: - مشاركته بنفسه في الأنشطة التعليمية المختلفة.

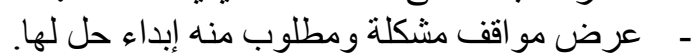

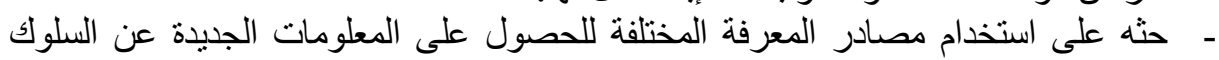

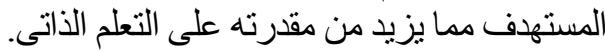

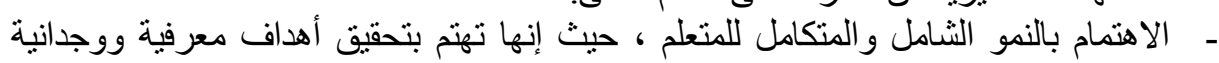

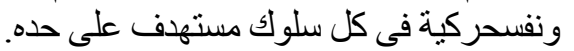
- رسم خر ائط سلوكية خاصة بالمتعلم ويستطيع من خلالها نوجيه سلوكه بنفسه و التخطيط

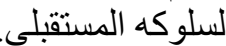

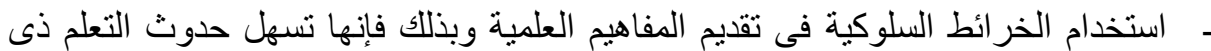

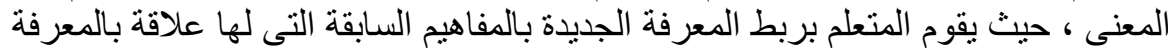

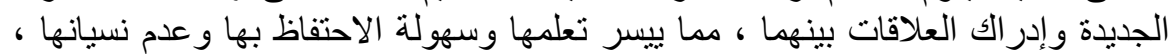

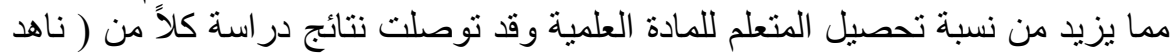

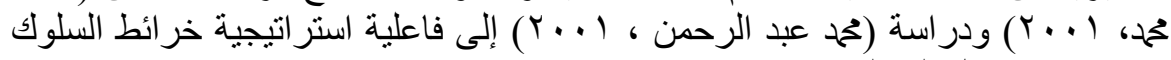

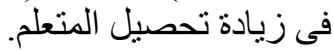

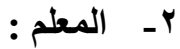
تساعد المعلم على : إنخاذ قرارات عن كيفية استخدام الوقت المحدد للفصل بشكل أكثر إنتاجية لأن لديه تصور اً واضحاً لما يحاول أن يحققه. 


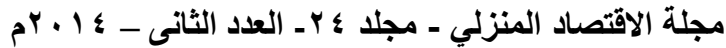

جعل عملية التدريس فعاله ، حيث توضح طريقة تتابع وتسلسل خطو ات سير الدرس مما

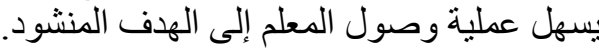
التركيز على سلوك محدد يريد إكسابه للمتعلم ويتتاوله من جو الب متعددة ومتنو عة فى الكى

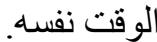
تحديد كيفية إجر اء التعديلات فى سلوك طلابه بما يتمانشى مع سماتهم الثخصية .

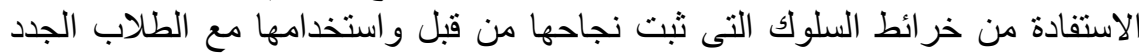

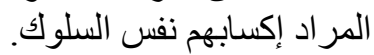
قامت الباحثة بإعداد المواد و الأدوات التالية : إجراءات البحث : البكاب: أدوات البحث : أبات

(أ) تم إلتداد أدوات البحث وهم:

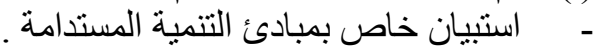

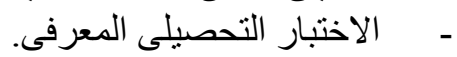

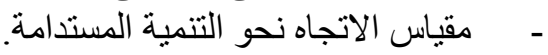
إعداد الاستبيان : إعنيان

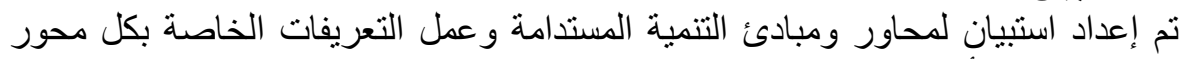

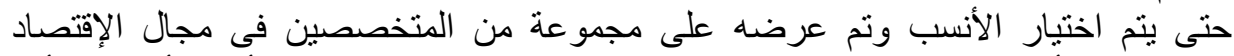

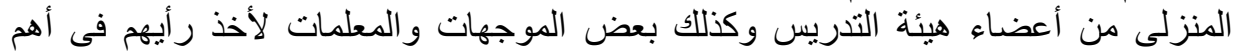

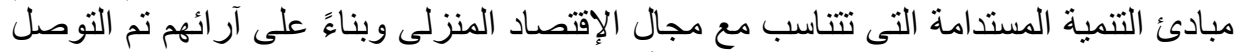

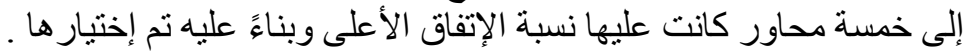
إعداد الاختبار التحصيلى:

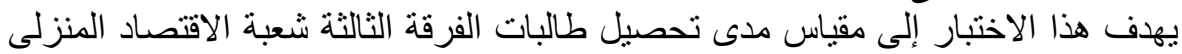

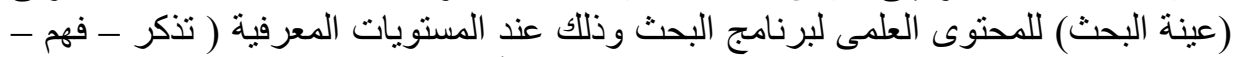

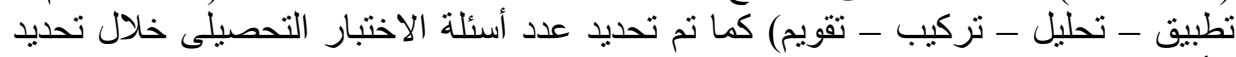

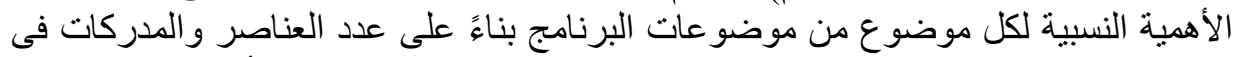
كل موضوع وقد صيغت عبار ات الاختبار من نوع عن الاختبار من متعدد ذئى الأربعة بدائل.

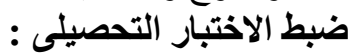
صدق وثبات الاختبار التحصيلي : ا يتعلق موضوع صدق الاختبار بما يقيسه الاختبار و إلى أي حد ينجح في قياسه . الصدق المنطقي :

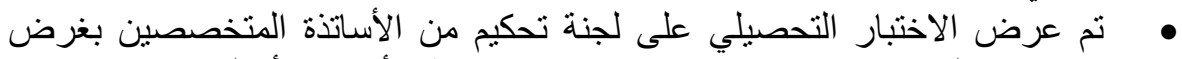

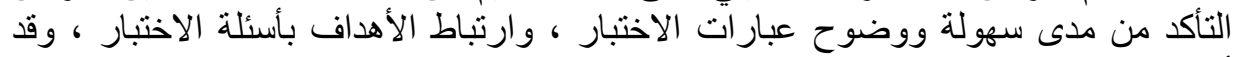

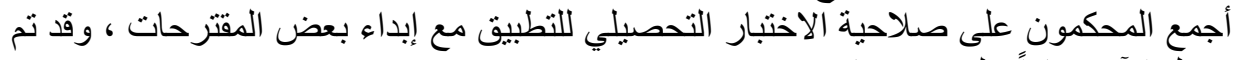

$$
\begin{aligned}
& \text { تعديل الآتي بناءاً على مقترحاتهم : } \\
& \text { تقليل عدد الأسئلة . } \\
& \text { مر اعاة سهولة ووضوح الصياغة . }
\end{aligned}
$$




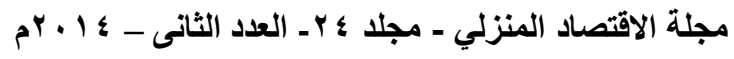

: ب الثبات يقصد بالثبات أن يكون الاختبار منسقاً فيما يعطي من النتائج ، وقد تم حساب معامل ثبات الاختبار التحصيلي بالطرق الآتية : الآنات

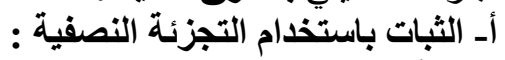

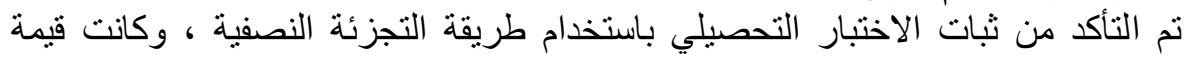

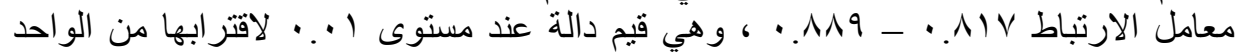

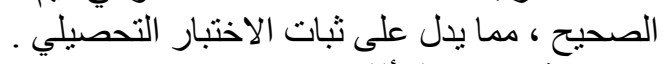

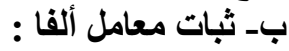

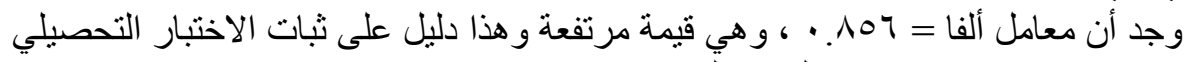

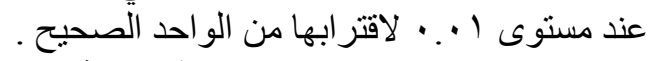
جدول (1) ثبات الاختبار التحصيلي

\begin{tabular}{|c|c|c|c|c|}
\hline \multicolumn{2}{|c|}{ معامل ألفا } & \multicolumn{2}{|c|}{ التجزئة النصفية } & \multirow{3}{*}{ ثتبات الاختبار } \\
\hline الالالة & قيم الارتباط & الالالة & قيم الارتباط & \\
\hline$\because 1$ & $\because \wedge 07$ & $\because \cdot 1$ & $\begin{array}{r}-\because \wedge 1 \vee \\
\cdot \wedge \wedge q\end{array}$ & \\
\hline
\end{tabular}

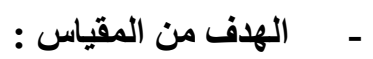

تحدد الهدف من المقياس فى قياس اتجاهات الطالبات المعلمات نحو التنمية المستدامة. - مباغة عبار ات المقياس. تم استخدام طريقة ( ليكرت ) لتصميم مقياس الاتجاهات ، وروعى أن تكون العبارات مصاغة بطريقة واضحة وتحتوى عبار ات المحاور على موضوع المحور بصورة صريحة أو لون وتبعاً لطريقة (ليكرت ) يحتوى المقياس على عبار ات موجبة وسالبة معاً كما تتطلب هذه ضمنية .

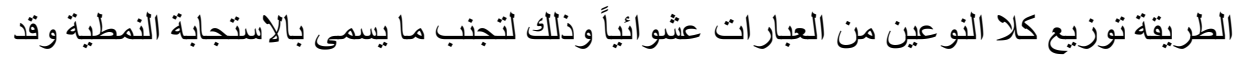
بلغ عدد المحاور خمسة محاور ولكل محور عشر عبار ات فأصبحت المفردات بالمقياس عددها

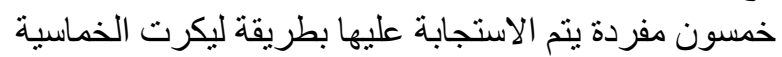
صدق مقياس الاتجاهات نحو التتمية المستدامة : مفردة الأبة

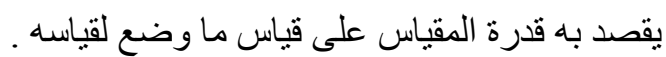

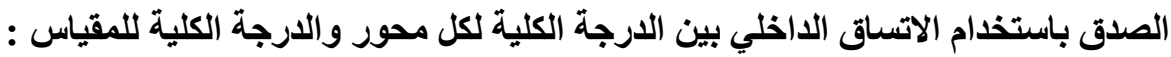
تم حساب الصدق باستخدام الاتساق الداخلي وذلك بحساب معامل الارتباط (معامل

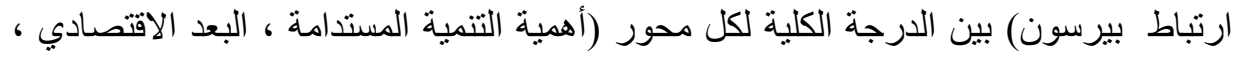

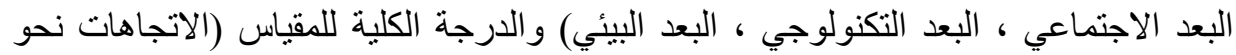
التتمية المستدامة) ، و الجدول التعالي العدي يوضح ذللك : 


$$
\text { مجلة الاقتصاد المنزلي - مجلد ع r ـ العدد الثانى - ع ا ـ ام }
$$

جدول (ץ) : قيم معاملات الارتباط بين درجة كل محور ودرجة مقياس الاتجاهات نحو

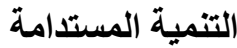

\begin{tabular}{|c|c|c|}
\hline الدلالة & الارتباط & المحاور \\
\hline$\because \cdot 1$ & $\because .191$ & المحور الأول : أهمية التنمية المستدامة \\
\hline$\because 1$ &. VMr & المحور الثاني : البعد الاقتصادي \\
\hline$\because 1$ & $.9 Y \varepsilon$ & المحور الثالث : البعد الاجتماعي \\
\hline$\because 1$ & $\because \Lambda \cdot Y$ & المحور الرابع : البعد التكنولوجي \\
\hline$\because \cdot 1$ &.$\vee \vee 0$ & المحور الخامس : البعد البيئي \\
\hline
\end{tabular}

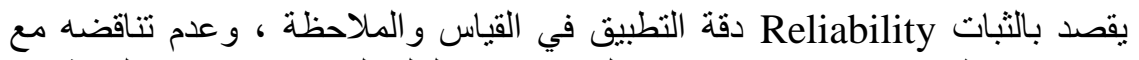

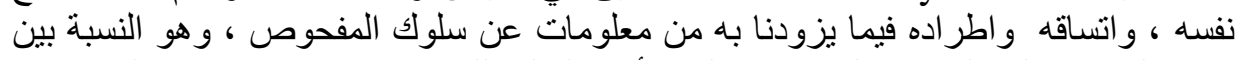
تباين الدرجة على المقياس التي تشير إلى الأداء الفعلي للمفحوص على ، و و تم حساب الثبات عن الثن

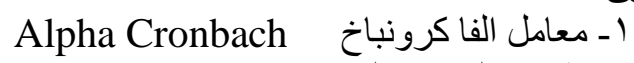

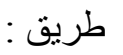

r- بريقة التجزئة النصفية

جدول (r) قيم معامل الثبات لمحاور مقياس الاتجاهات نحو التنمية المستدامة

\begin{tabular}{|c|c|c|}
\hline التجزئة النصفية & معامل الفا & المحاور \\
\hline$. .9 \varepsilon \cdot-. \wedge \vee 0$ & $.91 \mathrm{~V}$ & المحور الأول : أهمية التتمية المستدامة \\
\hline$. \vee \vee \vee q-\cdot . \vee \cdot$. &..$V \varepsilon r$ & المحور الثاني : البعد الاقتصادي \\
\hline$. . \wedge q 1-\cdot . \wedge r r$ &.$\wedge 70$ & المحور الثالث: : البعد الاجتماعي \\
\hline$\cdot .940-\cdot .19 V$ &. $.9 \cdot 1$ & المحور الرابع : البعد التكنولوجي \\
\hline$. . \wedge r Y-\cdot . V O r$ & $\because \vee \vee q \leq$ & المحور الخامس : البعد البيئي \\
\hline$\cdot . \wedge 9 \%-. .891$ & $\cdot . \wedge \mu$ & ثبات المقياس ككل \\
\hline
\end{tabular}

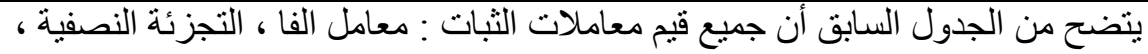

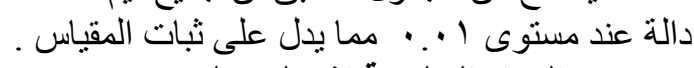

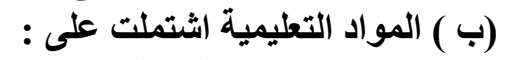

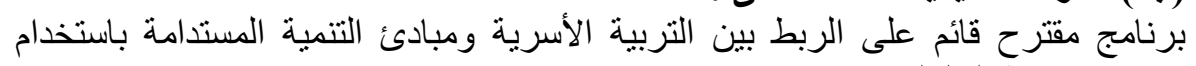

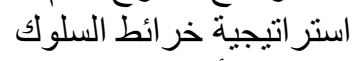

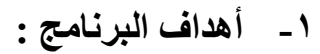

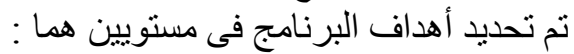
الأهداف العامة للبرنامج ، و الأهداف الإجر فئئية في ملحق رقم ( )

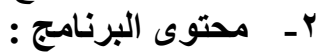

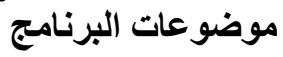
تم صياغة قائمة الموضونو عات فئ شكلها النهائى كما هو فى ملحق رقم (r) r- ستطلاع رأى السادة المحكمين حول البرنامج 


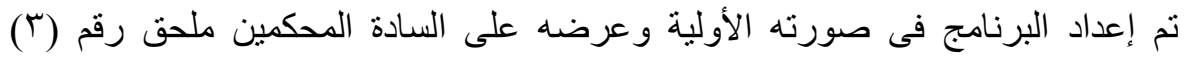

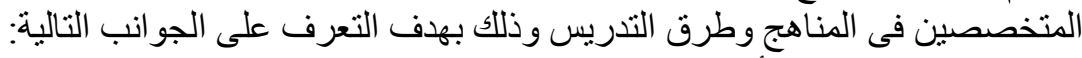

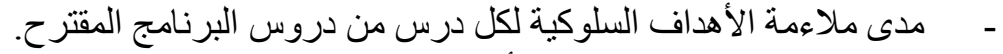

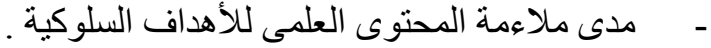

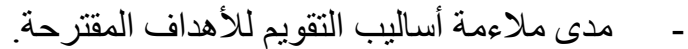

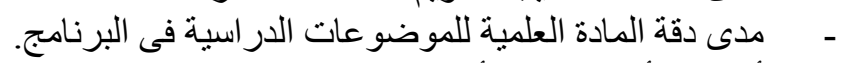
- - أية آراء أو مقترحات أخرى ير غب السبادة المحكمون في إبدائها .

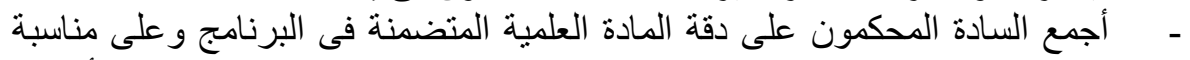

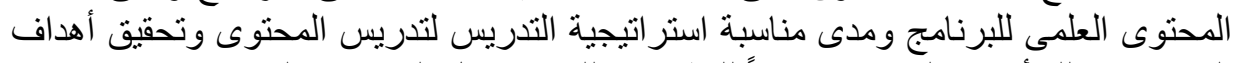

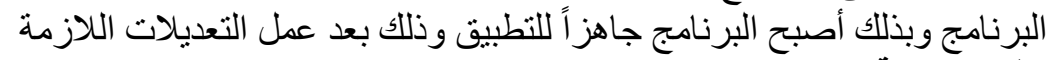

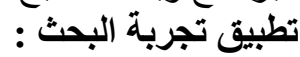
التطبيق القبلى لأدوات البحث : البحث :

- ـ تم تطبيق اختبار التحصيل المعرفى ومقياس الاتجاه نحو التنمية المستدامة على عينة البحث قبلياً.

- بدء تنفيذ التجربة وتطبيق البرنامج على الطلبات المعلمات فى الفصل الدراسى الأول $r \cdot 1 \leqslant / r+1 T$

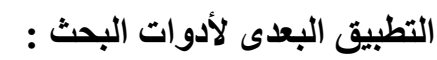

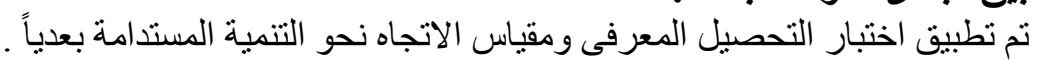

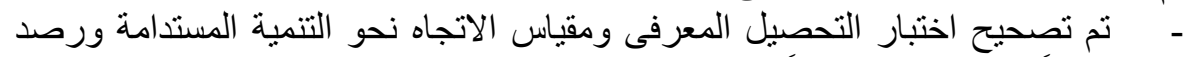
درجاتهم تمهيداً لمعالجاتها احصائياً والوصول إلى النتائج وتحليلها وتفسير ها. نتائج البحث وتعليلها:

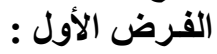
ينص الفرض الأول على ما يلي : الأليا

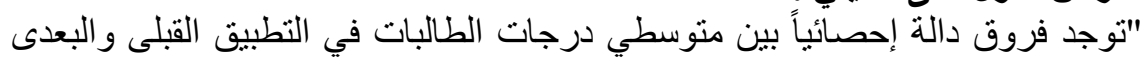

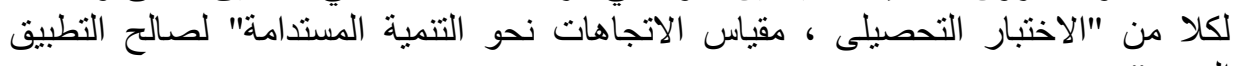
أو يحقق البرنامج المقترح فاعلية فى التحصيل وتنمية الاتجاه نحو التنمية المستدامة

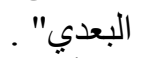
للطالبات عينة البحث البرن

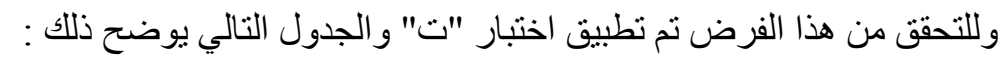

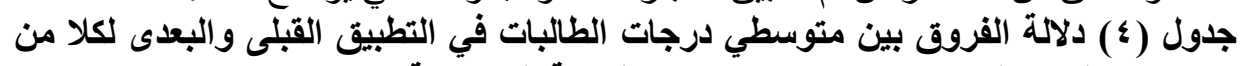

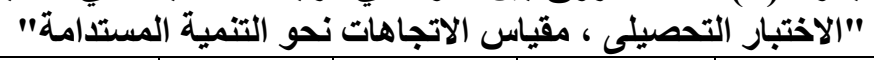

\begin{tabular}{|c|c|c|c|c|c|c|}
\hline واتجاهتوي & قيمـة ت & "درجــات & "الطالبات & الأنحراف أعياري & الحسابي & الفاعلية \\
\hline \multirow{2}{*}{ لصالح اللبعدى } & \multirow{2}{*}{$\varepsilon r .0, r$} & \multirow{2}{*}{19} & \multirow{2}{*}{ r. } & 1.001 & 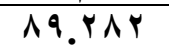 & القبالـي \\
\hline & & & & $1 \varepsilon .091$ & YOY.VIV & البعـدي \\
\hline
\end{tabular}




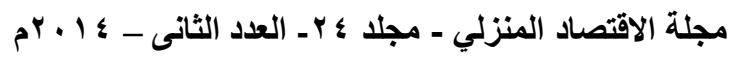

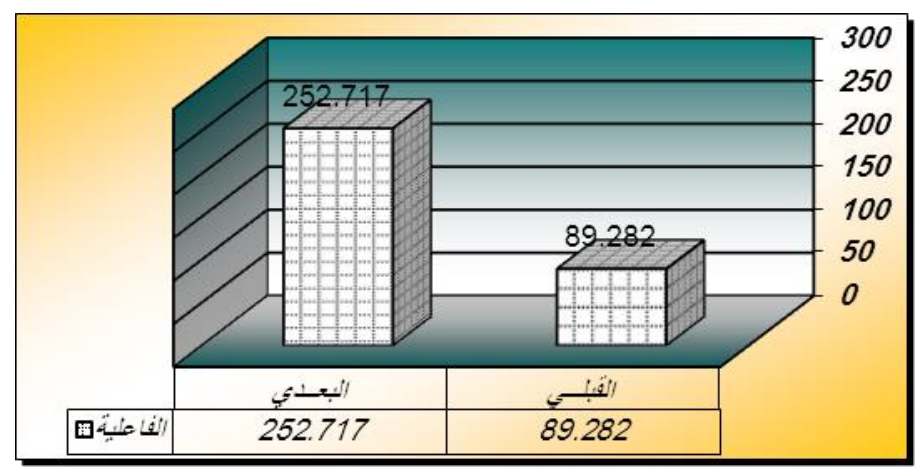

شكل ( 1): يوضح الفروق بين متوسطي درجات الطالبات في التطبيق القبلي والبعدى لكلا

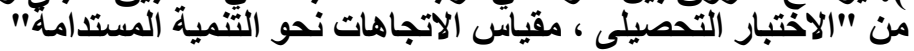

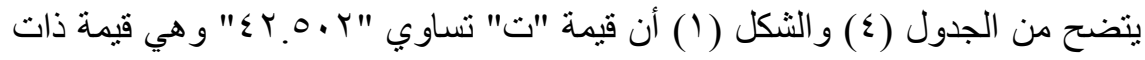

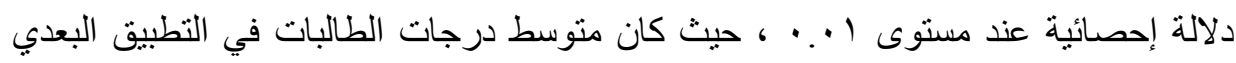

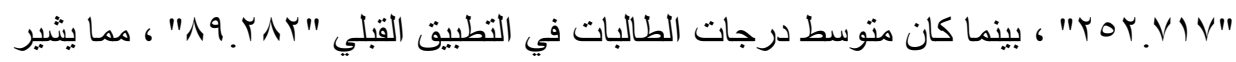
إلى وجود فروق حقيقية بين التطبيقين لصالح التطبيق البعدي ، أي أن البرنامج المقترح في هذه الدر اسة ناجح في تحقيق الهدف منه . و هذا يعنى أن حجم التأثير كبير ، وبذلك يتحقق الفرض الأول . الفرض الثاني : ينص الفرض الثاني على ما يلي : "توجد فروق دالة إحصائياً بين متوسطي درجات الطالبات في التطبيق القبلى و البعدى للاختبار التحصيلى في البرنامج المقتر حلصالح التطبيق البعدي" . وللتحقق من صحة هذا الفرض تم تطبيق اختبار "ت" و الجدول التالي يوضح ذلك : جدول (•): دلالة الفروق بين متوسطي درجات الطالبات في التطبيق القبلى والبعدى للاختبار التحصيلى

\begin{tabular}{|c|c|c|c|c|c|c|}
\hline واتجالتة & قيمة ت & "المريـة & "الطالبات & الالحعراف & "المستوسطي & التحصيلي \\
\hline \multirow{2}{*}{ لالبالح } & \multirow{2}{*}{10.991} & \multirow[b]{2}{*}{19} & \multirow[b]{2}{*}{$r}$. & $1.7 \mathrm{rr}$ & V.Y90 & القبلـي \\
\hline & & & & $r .90$ & rr.rlo & البعدي \\
\hline
\end{tabular}


مجلة الاقتصاد المنزلي - مجلد ع r ـ العدد الثانى - ع ا ب م

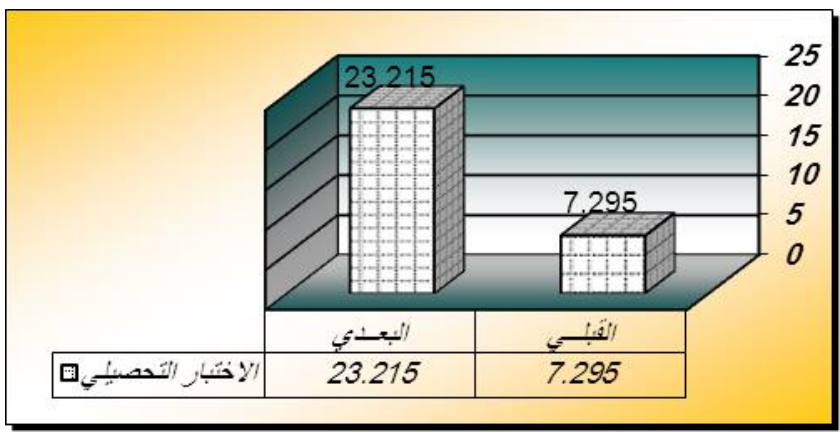

شكل (Y): يوضح الفروق بين متوسطي درجات الطالبات في التطبيق القبلى والبعدى للاختبار التحصيلى

يتضح من الجدول (0) و الشكل (r) أن قيمة "ت" تساوي "ا(99.9 1" للاختبار

التحصيلي ، وهي قيمة ذات دلالة إحصائية عند مستوى I •. • لصالح التطبيق البعدى ، حيث كان متوسط درجات الطالبات في التطبيق البعدي "ه اب.بr" ، بينما كان متوسط درجات الطالبات في التطبيق القبلي "هو ؟.V" ، وبذللك يتحقق الفرض الثاني

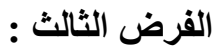

ينص الفرض الثالث على ما يلي :

"توجد فروق دالة إحصائياً بين متوسطي درجات الطالبات في التطبيق القبلى والبعدى

لمقياس الاتجاهات نحو التنمية المستدامة لصالح التطبيق البعدي" .

وللتحقق من صحة هذا الفرض تم تطبيق اختبار "ت" و الجداول التالية توضح ذلك :

جدول (7) دلالة الفروق بين متوسطي درجات الطالبات في التطبيق القبلى والبعدى

للمحور الأول "أهمية التتمية المستدامة"

\begin{tabular}{|c|c|c|c|c|c|c|}
\hline واتجالاكةى & قيمة ت & "الحرجــات & "الطالبات & الانحرافياري & 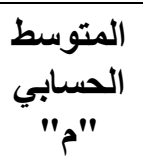 & المسية التمية أهمية \\
\hline \multirow{2}{*}{ ل' لـالّح } & \multirow[b]{2}{*}{ rr.VYq } & \multirow[b]{2}{*}{19} & \multirow[b]{2}{*}{$r$. } & $1 . \mu r$ & I MOY & القبلـي \\
\hline & & & & ג צ. & ะ . $77 \mathrm{~V}$ & البعـدي \\
\hline
\end{tabular}


مجلة الاقتصاد المنزلي - مجلد ع بـ العدد الثانى - ع ا ب بم

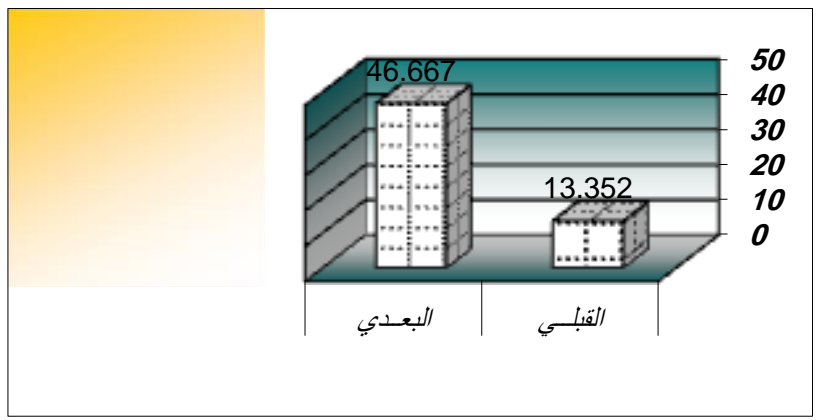

شكل (ّ) : يوضح الفروق بين متوسطي درجات الطالبات في التطبيق القبلى والبعدى

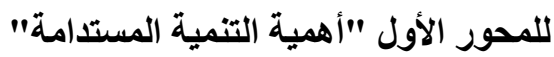

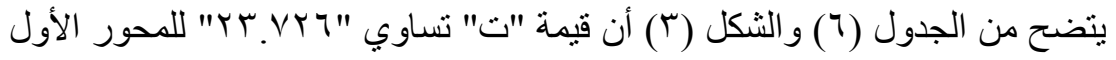

"أهمية التنمية المستدامة" ، و هي قيمة ذات دلالة إحصائية عند مستوى ا .. • لصالح التطبيق

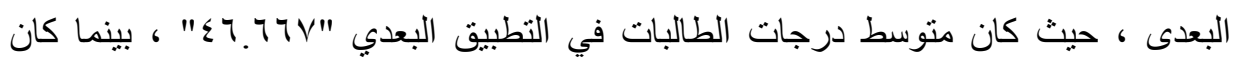

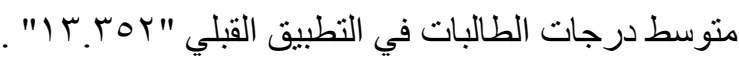
جدول (V) : دلالة الفروق بين متوسطي درجات الطالبات في التطبيق القبلى والبعدى للمحور الثاني "البعد الاقتصادي"

\begin{tabular}{|c|c|c|c|c|c|c|}
\hline واتجالائة & قيمة ت & "درجـات & "الطالبات & المعياري & المسابي المتوسط" & الاقتصادي البعد \\
\hline \multirow{2}{*}{ لصالح } & \multirow{2}{*}{18.900} & \multirow[b]{2}{*}{19} & \multirow[b]{2}{*}{$r}$. & $\because .910$ & $17.9 \leqslant V$ & القباـي \\
\hline & & & & $r_{.} \cdot \wedge \Lambda$ & $\varepsilon r_{.} \cdot \Lambda \Lambda$ & البعـدي \\
\hline
\end{tabular}




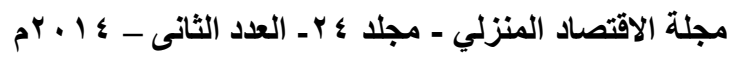

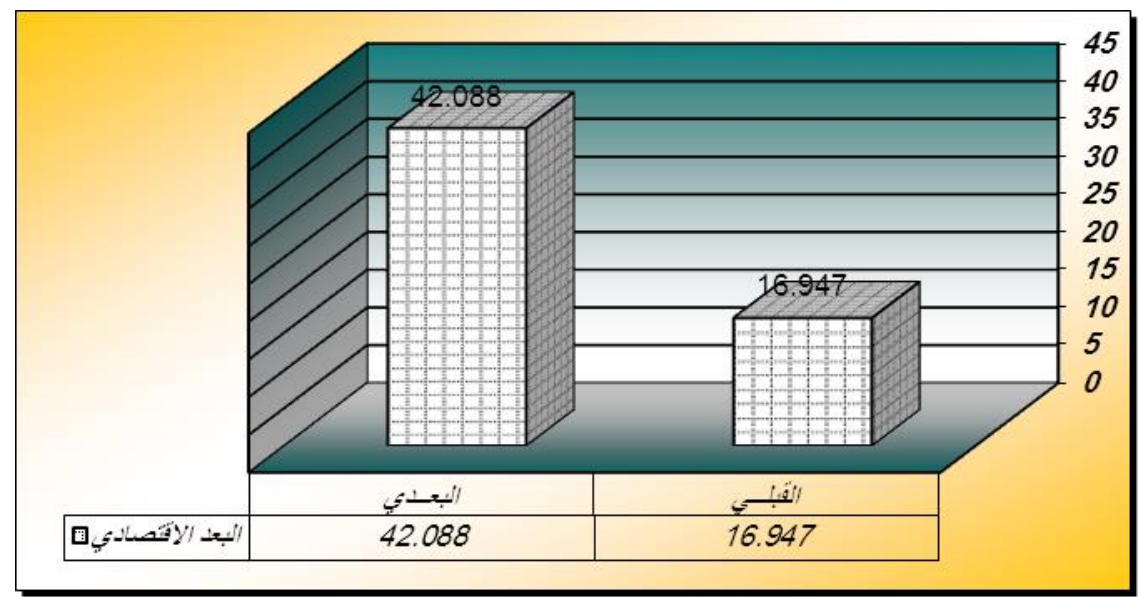

شكل ( )): يوضح الفروق بين متوسطي درجات الطالبات في التطبيق القبلى والبعدى

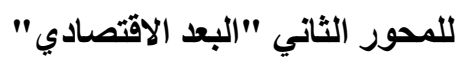

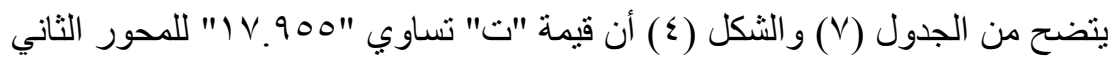

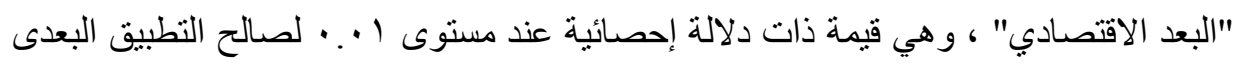

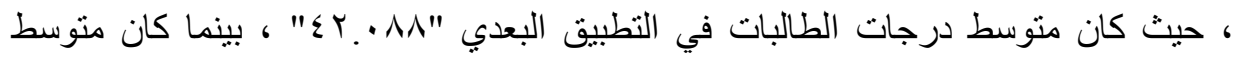

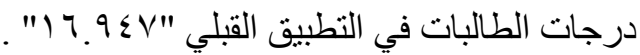

جدول (^) :دلالة الفروق بين متوسطي درجات الطالبات في التطبيق القبلى والبعدى

للمحور الثالث " البعد الاجتماعي" دروبئ

\begin{tabular}{|c|c|c|c|c|c|c|}
\hline واتلجالوي & قيمة ت & "درجـات & "الطالبات & المعياري & "الحستوسطي & الاجتماعي \\
\hline \multirow{2}{*}{ لالبالح } & \multirow[b]{2}{*}{ r. } & \multirow[b]{2}{*}{19} & \multirow[b]{2}{*}{$r$. } & $1 . \leqslant 1 Y$ & $r \cdot .1 Y \varepsilon$ & القبالـي \\
\hline & & & & r. & $\varepsilon \wedge . \wedge \diamond \wedge$ & البعـدي \\
\hline
\end{tabular}




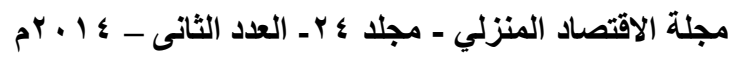

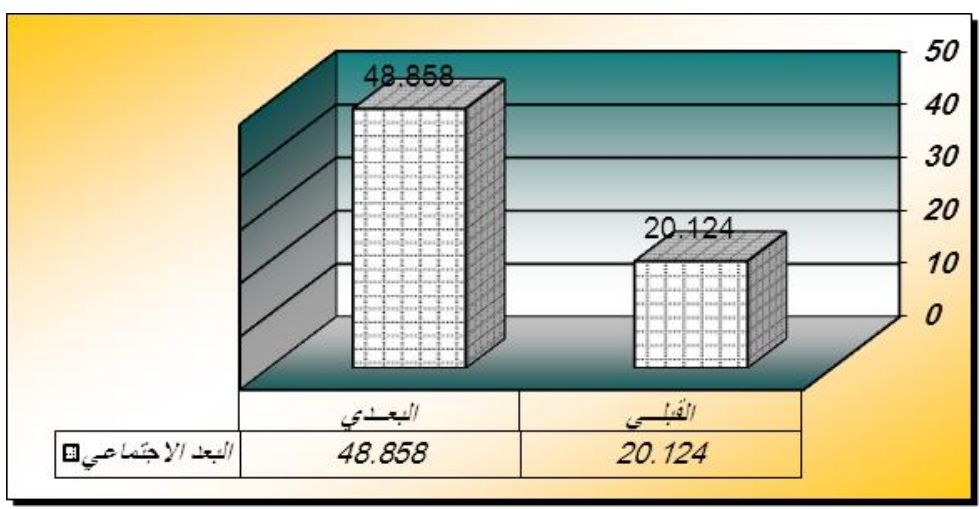

شكل (0) : يوضح الفروق بين متوسطي درجات الطالبات في التطبيق القبلى والبعدى

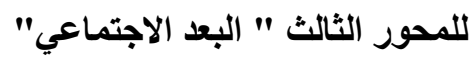

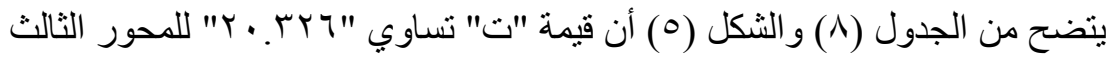

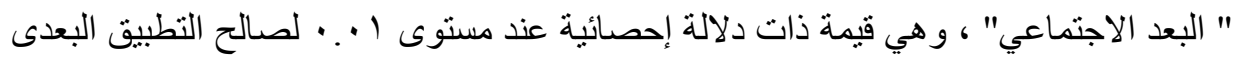

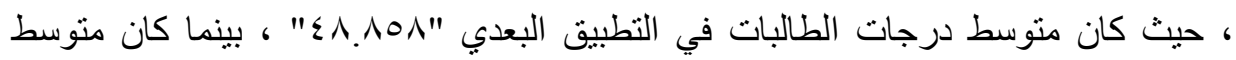

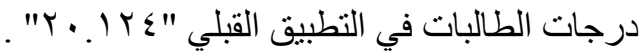

جدول (9) : دلالة الفروق بين متوسطي درجات الطلبات في التطبيق القبلى والبعدى للمحور

\begin{tabular}{|c|c|c|c|c|c|c|}
\hline ماتجاهنها & قيمة ت & "درجــات & "الطالبات & $\begin{array}{c}\text { الانحرافياري } \\
\text { "عياف" }\end{array}$ & "الحسابي & التكنولوجي البعد \\
\hline$\because \cdot 1$ & & & & $1.11 Y$ & 19.941 & القبلـي \\
\hline الصالح & $11.97 \mathrm{~V}$ & 19 & r. & $£ .770$ & $\varepsilon \varepsilon . \mu V$. & البعـدي \\
\hline
\end{tabular}

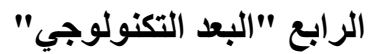




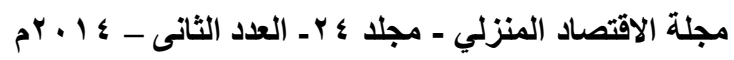

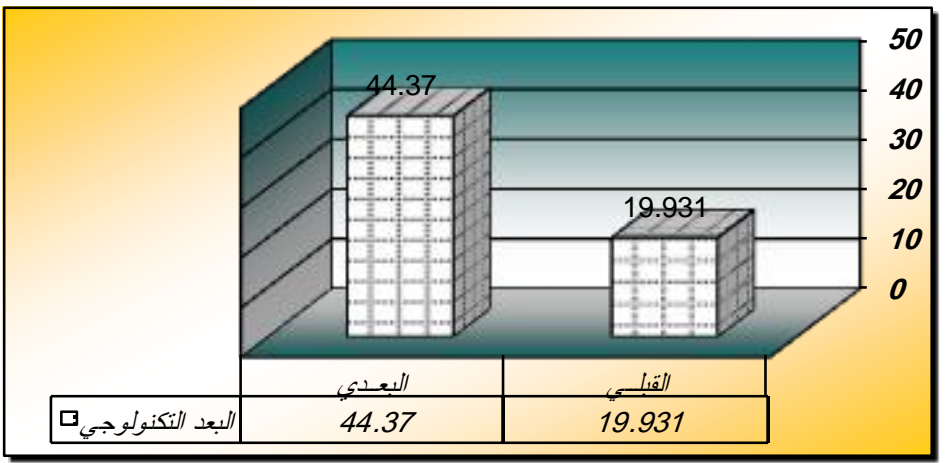

شكل (†): يوضح الفروق بين متوسطي درجات الطالبات في التطبيق القبلى والبعدى

للمحور الرابع "البعد التكنولوجي"

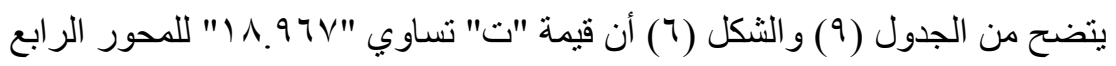

"البعد التكنولوجي" ، وهي قيمة ذات دلالة إحصائية عند مستوى ا .. • لصالح التطبيق البعدى

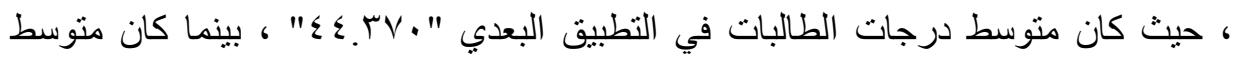

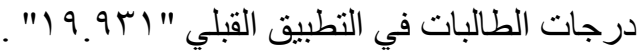
جدول (• 1) دلالة الفروق بين متوسطي درجات الطالبات في التطبيق القبلى والبعدى للمحور الخامس "البعد البيئي"

\begin{tabular}{|c|c|c|c|c|c|c|}
\hline والدالاهة & قيمة ت & لدرجـات & "الطالبات & الالانحراف & "المسابي & البيئي \\
\hline \multirow{2}{*}{ 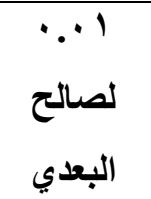 } & \multirow[b]{2}{*}{ ro.vor } & \multirow[b]{2}{*}{19} & \multirow[b]{2}{*}{$r}$. & 1.874 & $11.7 \mathrm{rr}$ & القبالـي \\
\hline & & & & r.rqr & $\varepsilon V .019$ & البعـدي \\
\hline
\end{tabular}




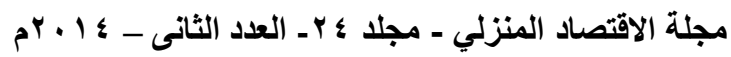

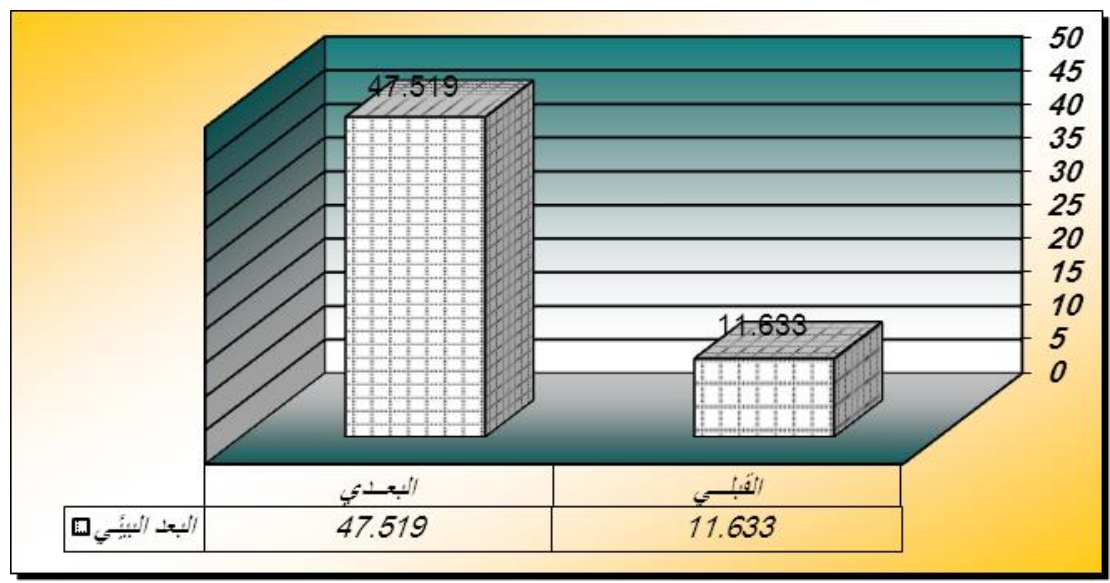

شكل (V) : يوضح الفروق بين متوسطي درجات الطالبات في التطبيق القبلى والبعدى

$$
\text { للمحور الخامس "البعد البيئي" }
$$

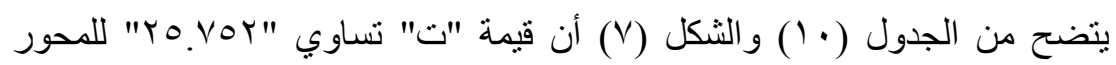
الخامس "البعد البيئي" ، وهي قيمة ذات دلالة إحصائية عند مستوى ا ... لصالح التطبيق

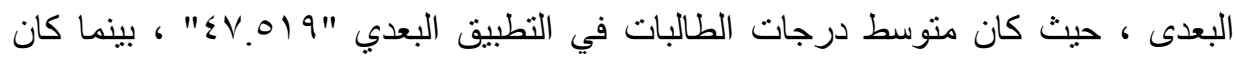

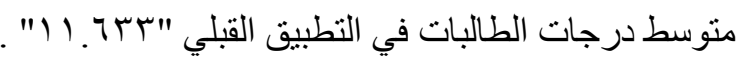
جدول (1 1 ) دلالة الفروق بين متوسطي درجات الطالبات في التطبيق القبلى والبعدى لمقياس الاتجاهات نحو التنمية المستدامة ككل

\begin{tabular}{|c|c|c|c|c|c|c|}
\hline مستوى & قيمة ت & "درجـات & "الطالبات & "الانحراف & "المسابي & للمقياس الكليوع \\
\hline \multirow{2}{*}{ 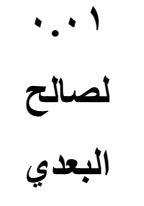 } & \multirow{2}{*}{ rq. rl. } & \multirow{2}{*}{19} & \multirow{2}{*}{$r}$. & 0.11. & $\wedge 1.9 \wedge \mathrm{V}$ & القبالـي \\
\hline & & & & $9.91 \%$ & $r r q .0 \cdot r$ & البعـدي \\
\hline
\end{tabular}




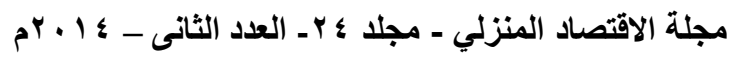

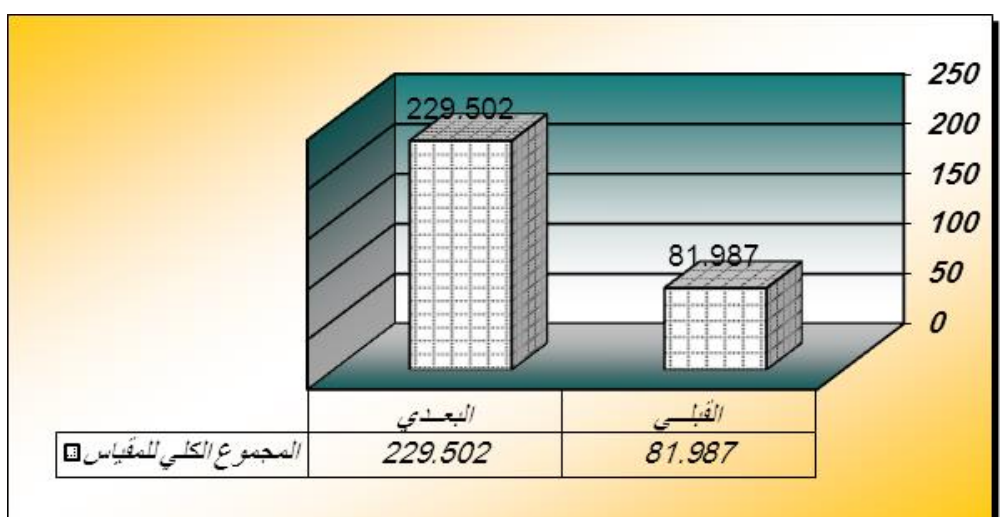

شكل (^): يوضح الفروق بين متوسطي درجات الطالبات في التطبيق القبلى والبعدى

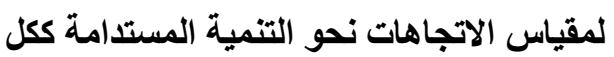

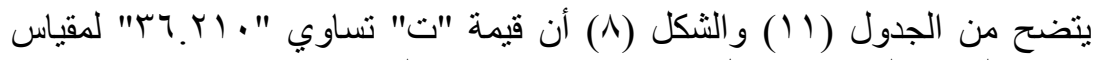

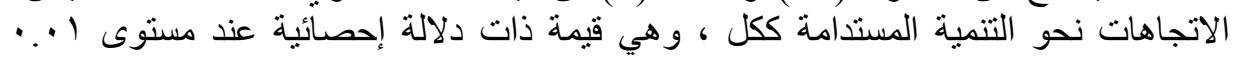

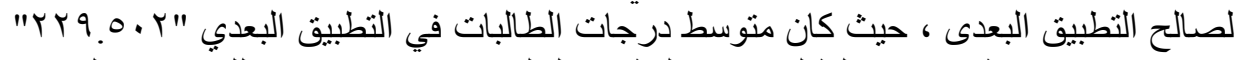

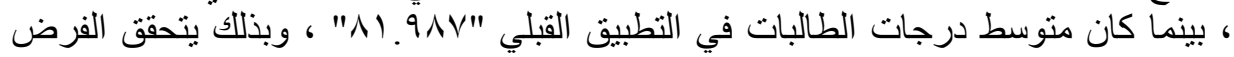

هدف هذا البحث إلى إعداد برنامج للربط بين مجالات التربية الأسرية والتنمية المستدامة

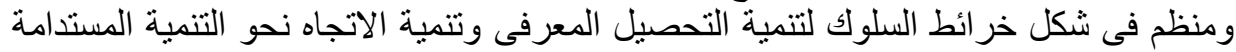
لاى طالبات شعبة الاقتصاد المنزلى كلية التربية النو عية بالاسكندرية.

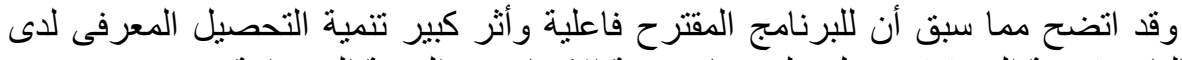

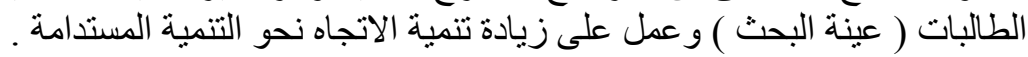

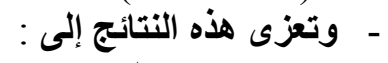

إن موضوعات البرنامج زودت إلى الطالبات بالمعرفة مما ساعدهن على تلى التمبية التحصيل

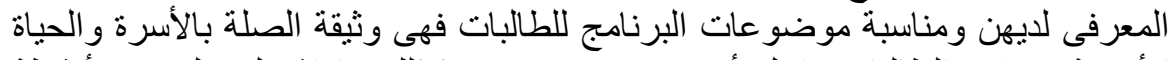

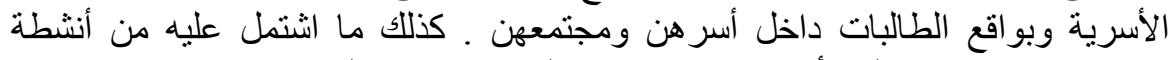

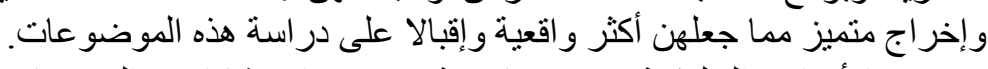

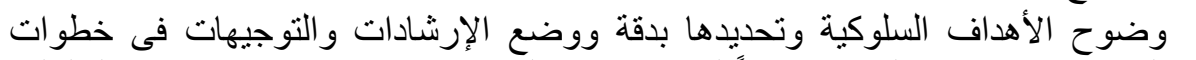

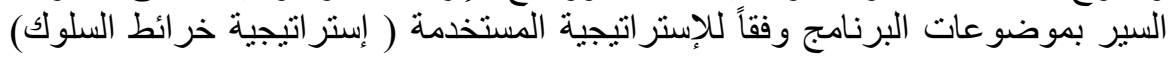

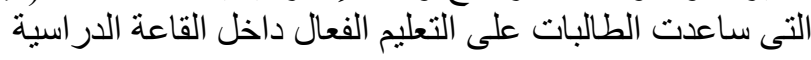

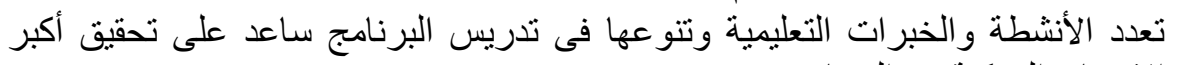

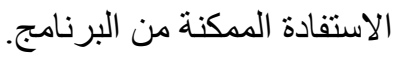

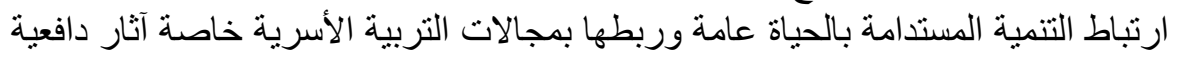
التعلم عند الطالبات لمعرفة التر ابط بين الاثنين. 


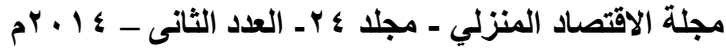

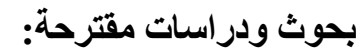

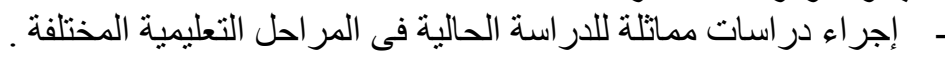

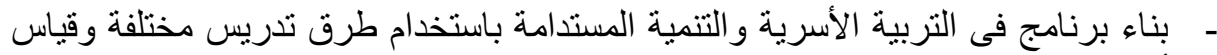

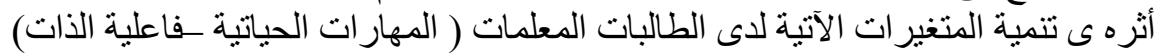

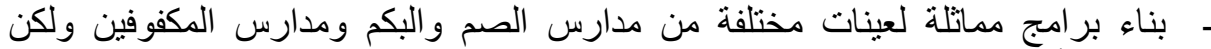
بطريقة أخرى مناسبة لهذه العينات.

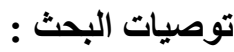

- الاهتمام بمفاهيم التتمية المستدامة فى مقررات اللائحة التدريسية للطلاب جميع الفرق وجميع المر احل الدر اسية.

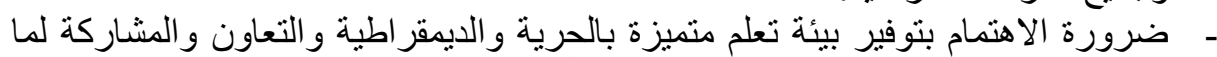

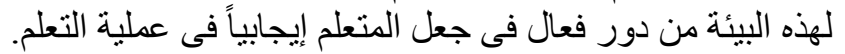

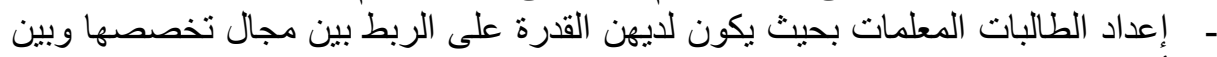

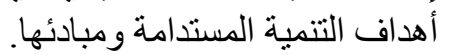

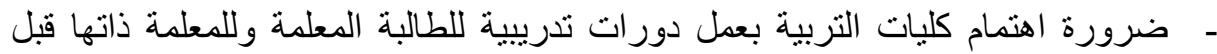

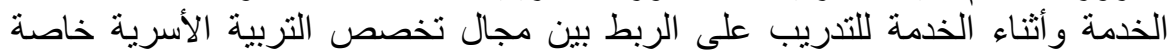

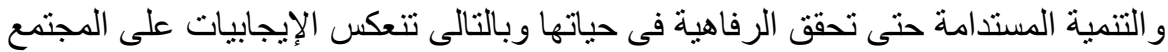

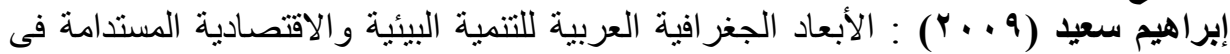

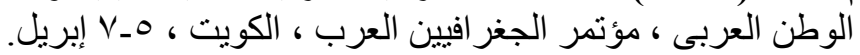

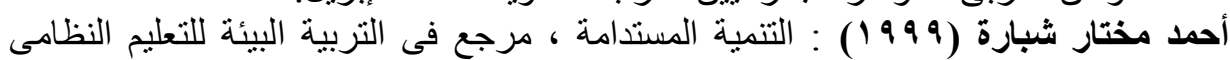

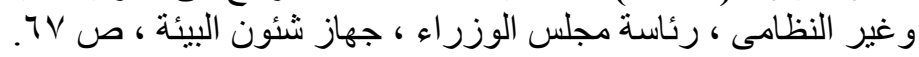

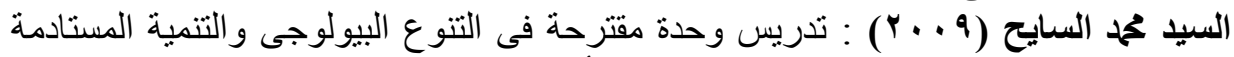

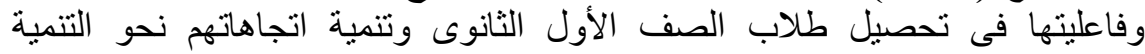

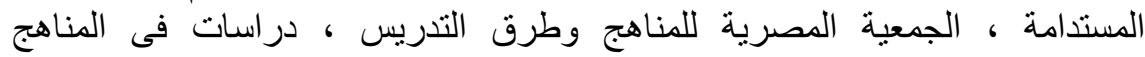
وطر قالتدريس، العدد 7 ـ ( ا، مايو.

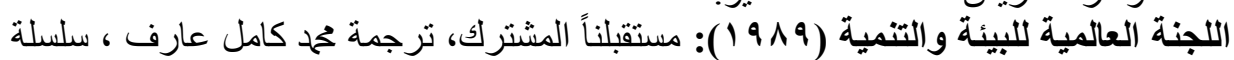

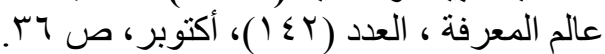

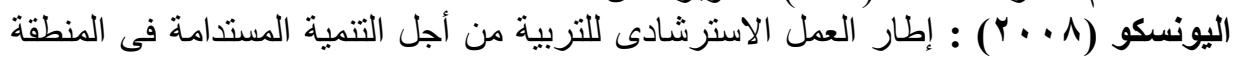

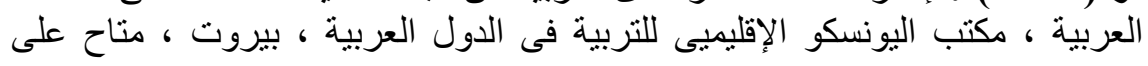
http://www.unesco/beirut

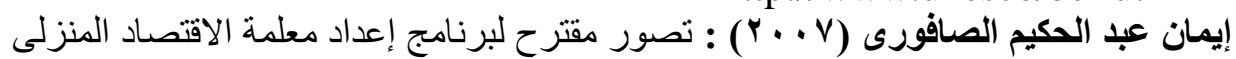

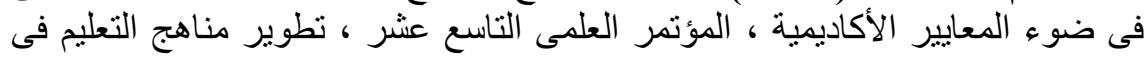

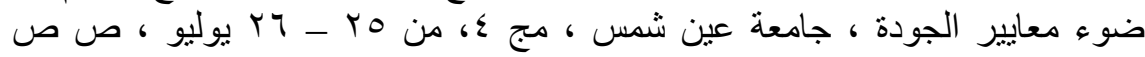
. $178 \cdot 170$.

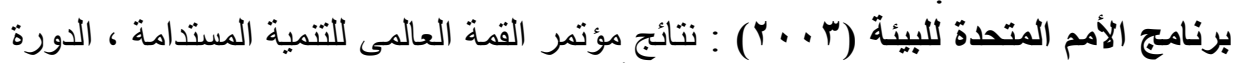

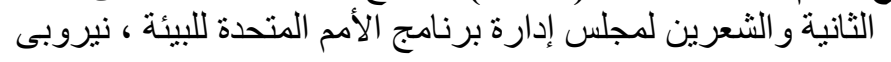




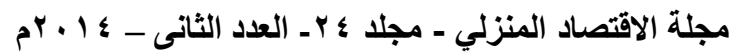

تسبى محمه رشاد ، إيزيس عازونوار (9 9 V 1 ): مدخل فى الاقتصاد المنزلى ، الاسكندرية ، دار

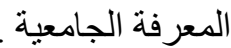

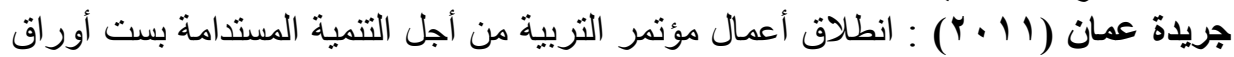

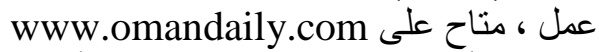

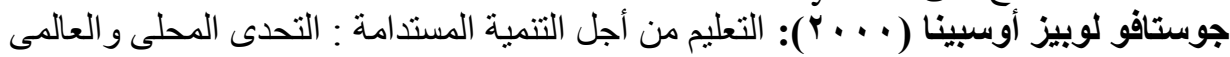

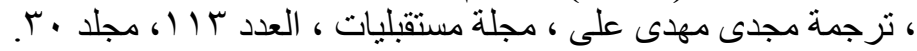

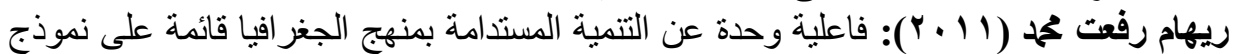

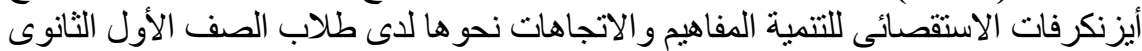

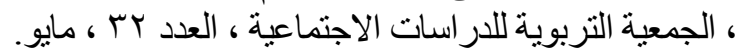

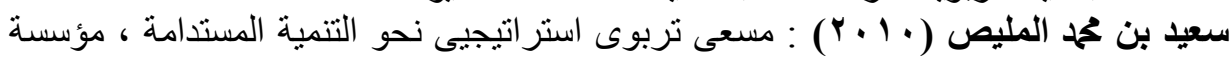

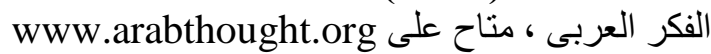

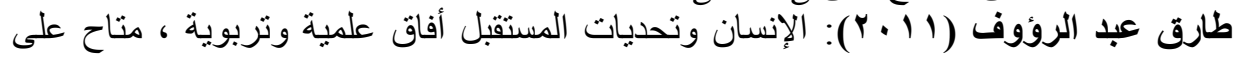
www.all3loom.com

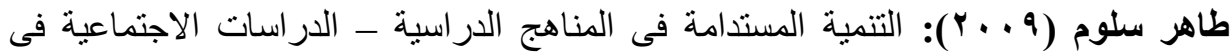

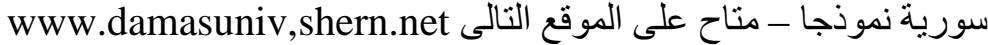

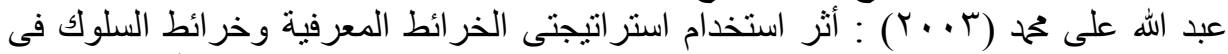

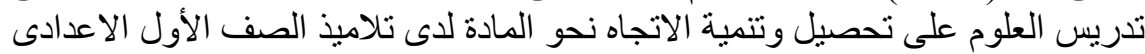

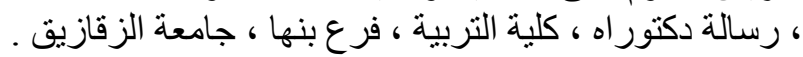

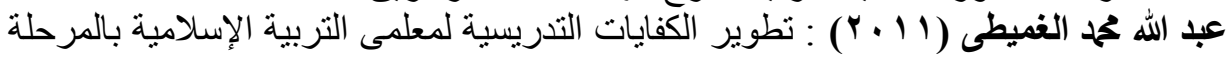

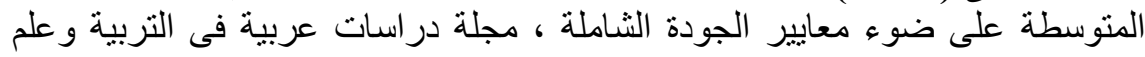

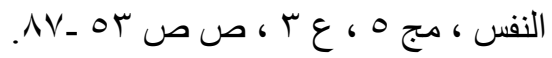

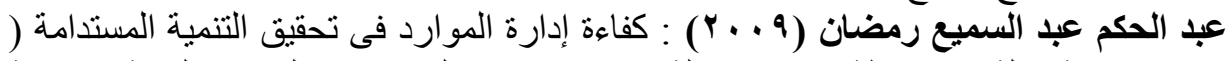

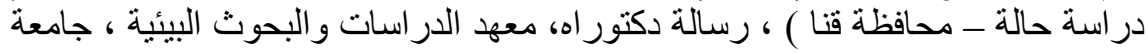
عين شمس. عبد الخالق عبد الله (ب 9 9 (1): التتمية المستدامة و العلاقة بين البيئة والتتمية ، مجلة المستقبل

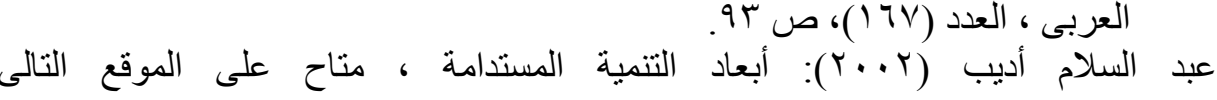
Www.ahewar.org

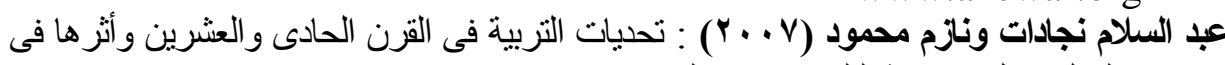

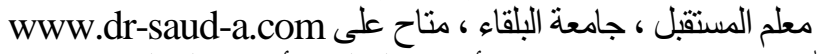

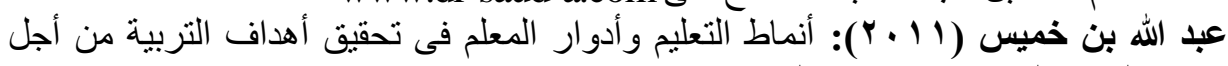

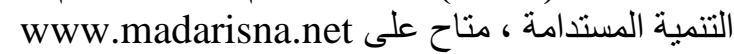

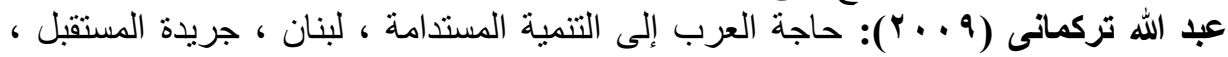

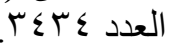

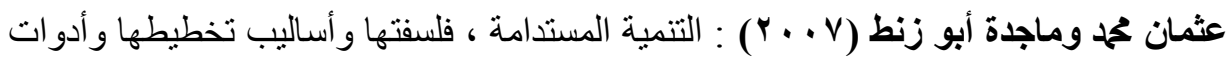

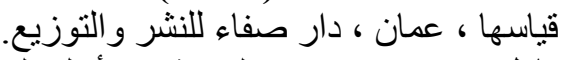

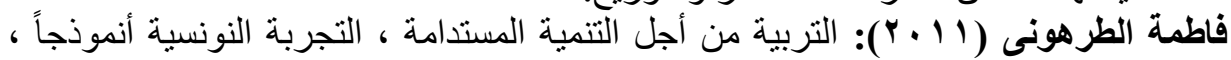

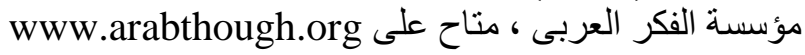




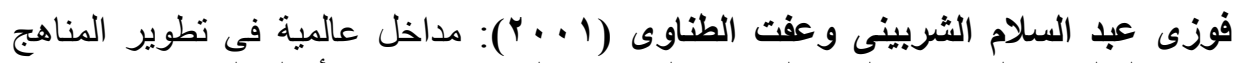

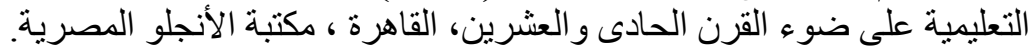

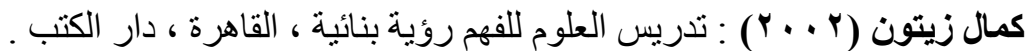

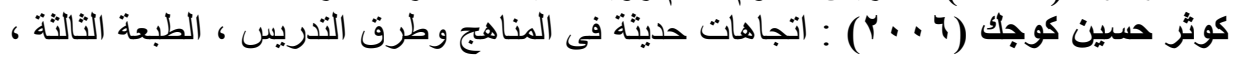

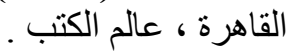

كوثر حسين كوجك ، ولول جيد (990 (199) ): المرجع فى التربية الأسرية ، طץ ، القاهرة، عالم

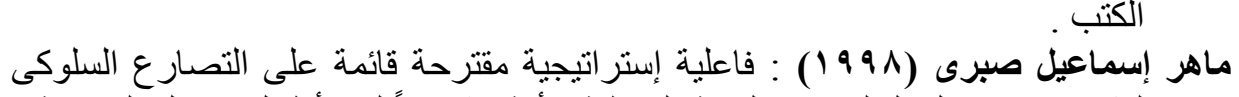

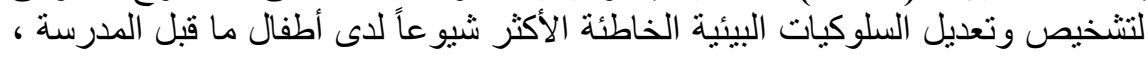

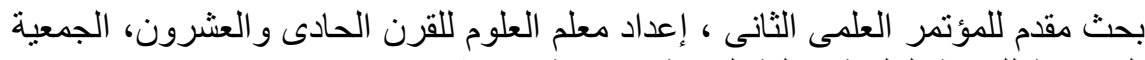

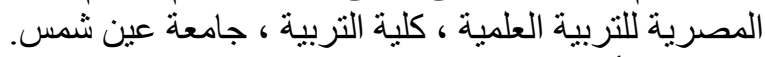

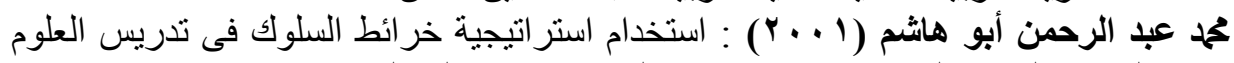

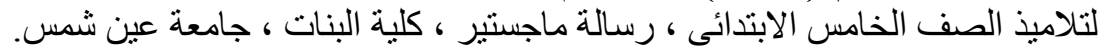

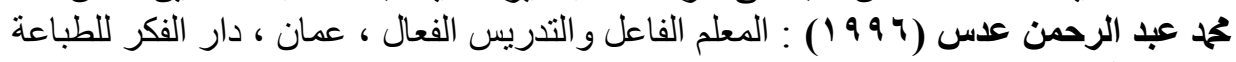

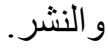

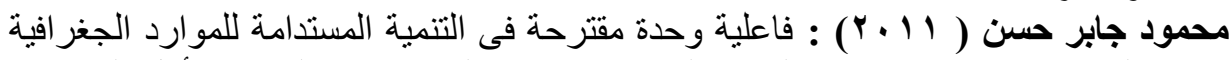

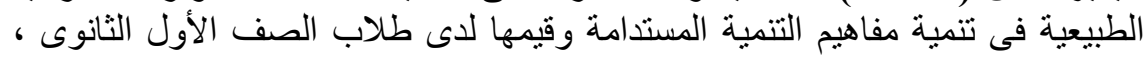

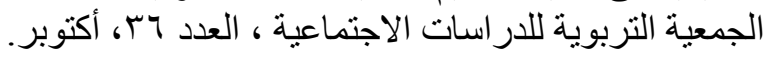

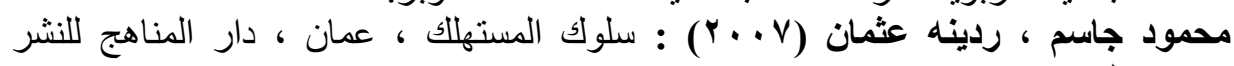

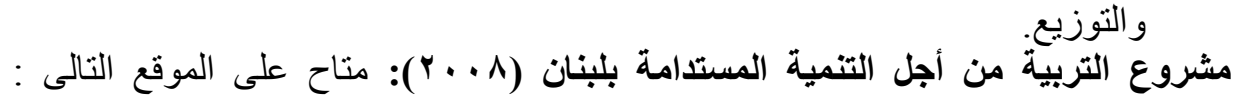
http://Www.crdp.org

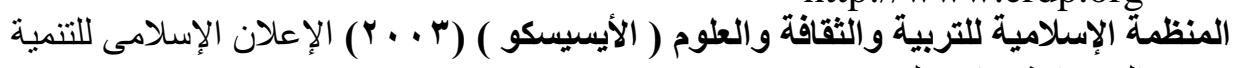

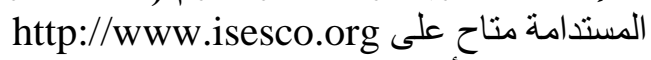

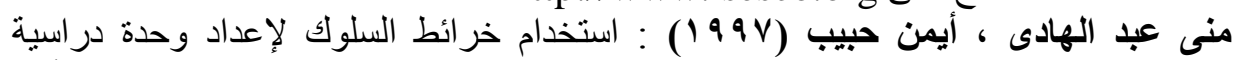

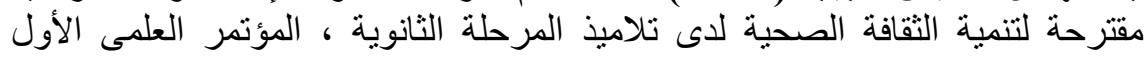

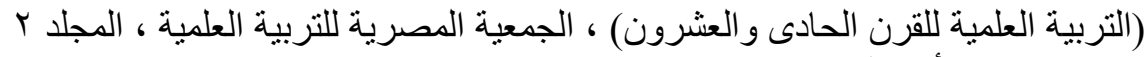

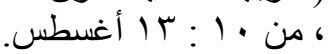

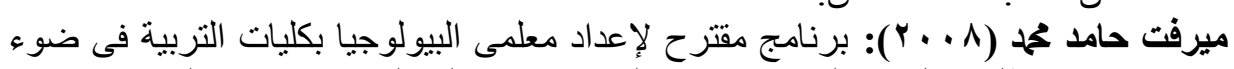

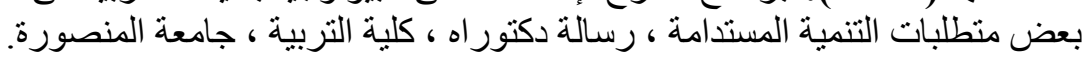

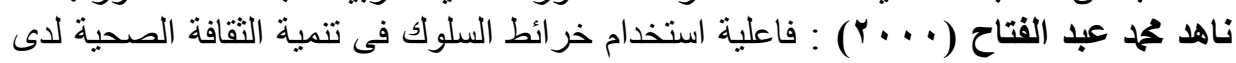

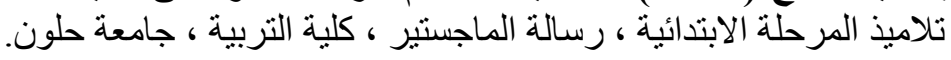

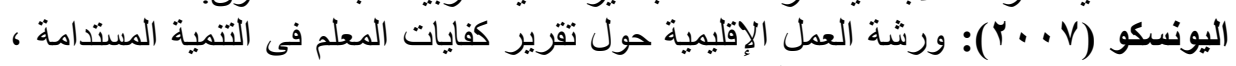

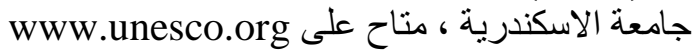

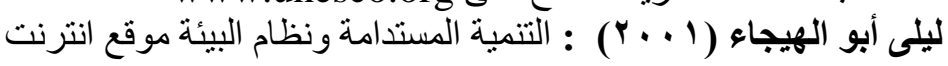
Http://www.sdnb.jo/tanmenh.mustadameh.html1 


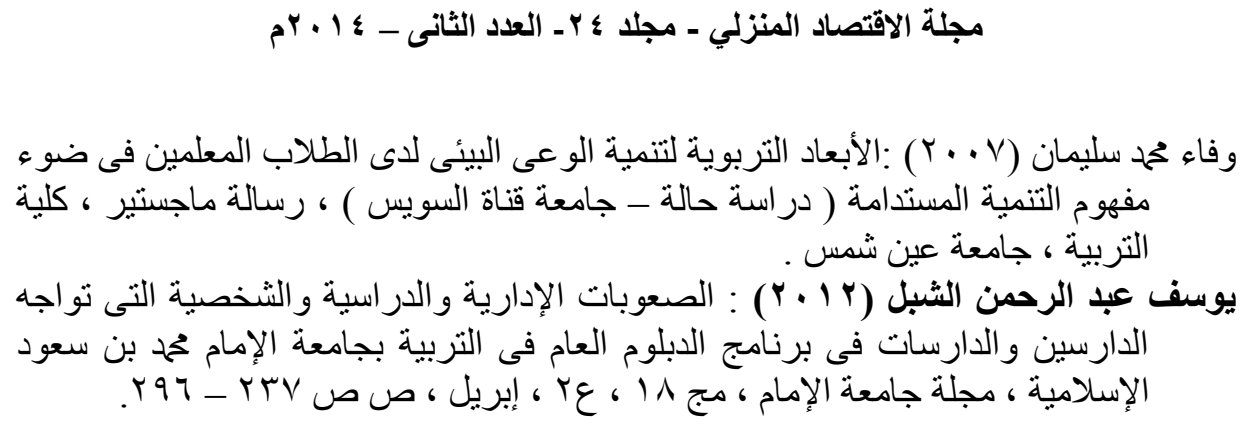

Abu- Hola, M \& Tareef, A . (2009). Teaching for Sustainable Development in Higher Education Institutions : Univesity of hordan as a Case Study College Student Journal , v43, n4, pp 1287 -135 , Dec

Acpa ( American College Personnel, Association ) - (2003) : Education for Sustainable Development, Washington, DC, USA.

Alam , G. (2009) : The role of science and technology education at network age population for sustainable development of Bangladesh through human resource advancement. Scientific Research and Essay Vol.4 (11). Available at http://www.academicjournals.org.

Blake, J. Weston, K \& Woolhouse, M (2011) : Embedding Education for Sustainable Development and Global Education concepts into teaching practice: the experience of student teachers, School of Education University of Hertfordshire.

Counvil of the European Union , (2010). Council conclusions on education for sustainable development, $3046^{\text {th }}$ Education, youth, culture and Sport Council meeting Brussels, 1-7.

CSCT ( Curriculum, Sustainable development Competences, Teacher training). (2008). Competencies for ESD ( Education for Sustainable Development) teachers A framework to integrate ESD in the curriculum of teacher training institutes. Comenius 2.1 Available at www.csct- project.org.

David, U. et al., (1997) :" Behavior Maps : charting the road to more appropriate student behavior, " Preventing school failure, Vol. 42, No.1.

De-Young, R. (1993): “ Changing behavior and making it stick the conceptualization and management of conservations behavior", environmental and behavior, The Journal of Environmental Education, Vol, No.4. 


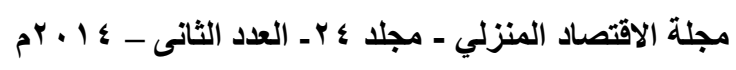

Farraji, H. (2009), Quality of Education Enhance Sustainable development . International Congress Geotuni, 1- 46

Hammers Chmidt (1996): The kirton adaption innovation inventory and group problem solving success rates Journal of Creative Behavior. Vol,30, N.1.

Harris, J (2000). Basic Principles of Sustainable Development Global Development and Environment Institute Tufts University, USA Available, http://ase,tufts.edu/gdae

John Oneill \& Clive L, Spash (2000) : “ Conceptions of value in environmrntal . Decision - making “, New York.

Jo,I., (2004). County Extension Agent. Fanily \&Consumer sciences “ Home Economics Hori zor " Texas Cooperative Extension. Harris County, 3-6

Parcel, G.S. \& Bronowiski, T. (1981): “ Social learning theory and health education " Health Education, Journal of Environmental Education Vil. 12

Vallis, A. (1994). History of elementary home economics programs in the van couver school District $1960-1992$.

Wooley Susan (1995) : “ Behavior mapping, A tool for identifying priorities for health education curricula and instruction" , Journal of health Education, July / August, Vol. 25, No. 4. 